\title{
MIDDLE EAST AND NORTH AFRICA
}

\section{First Regionalized Social Accounting Matrix for Egypt}

\section{A 2015 Nexus Project Social Accounting Matrix}

Josée Randriamamonjy, Mariam Raouf, and James Thurlow

Compiled in collaboration with the General Department of National Accounts at the Central Agency for Public Mobilization and Statistics (CAPMAS) of the government of the Arab Republic of Egypt 


\section{TABLE OF CONTENTS}

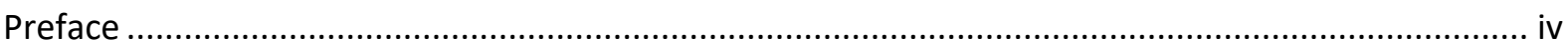

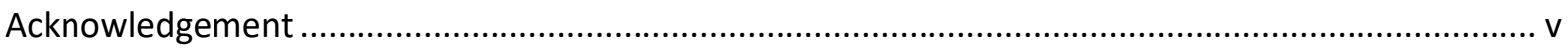

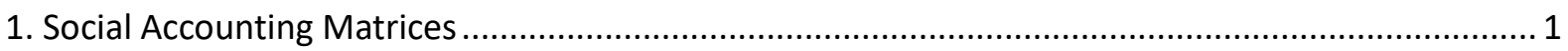

2. Standard Nexus Social Accounting Matrix Accounts ....................................................................... 3

3. Nexus Social Accounting Matrix Entries and General Data Sources............................................... 7

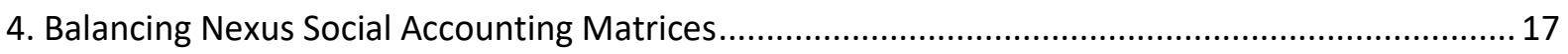

5. Egypt Social Accounting Matrix and Data Sources .................................................................. 18

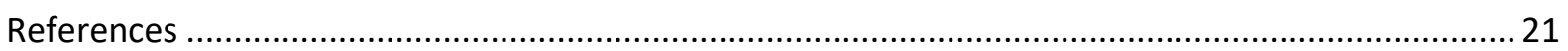

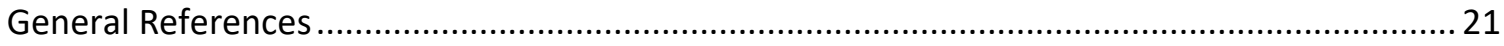

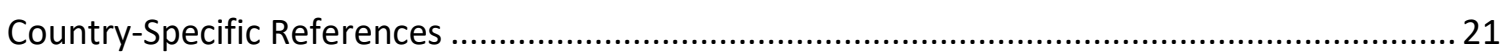

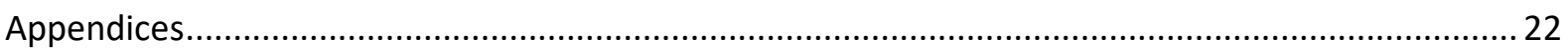

\section{LIST OF TABLES}

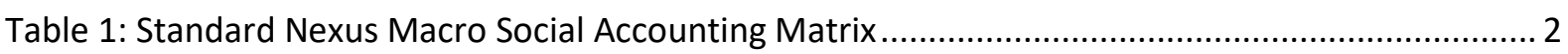

Table 2. Activities and Commodities in the Standard Nexus Social Accounting Matrix ........................ 4

Table 3. Factors in the Standard Nexus Social Accounting Matrix ....................................................... 4

Table 4. Household Types in the Standard Nexus Social Accounting Matrix........................................ 5

Table 5. Accounts in the Standard Nexus Social Accounting Matrix ................................................... 6

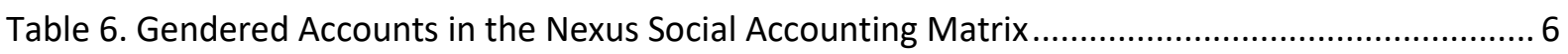

Table 7. Regional Accounts in the Nexus Social Accounting Matrix .................................................... 7

Table 8: Numbered Entries in a Standard Nexus Social Accounting Matrix ......................................... 8

Table 9. Summary of Data Sources for the Egypt Social Accounting Matrix ....................................... 18

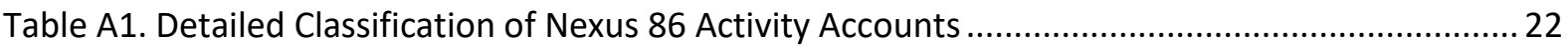

Table A2. Detailed Classification of Nexus 86 Agricultural Activity Accounts ..................................... 25

Table A3. Concordance between Nexus 70 and Nexus 86 Activity Accounts.....................................2 27

Table A4. Detailed Classification of the Government Account.......................................................... 28

Table A5. Detailed Classification of the Rest of World Account ........................................................29 


\section{ACRONYMS AND ABBREVIATIONS}

$\begin{array}{ll}\text { BOPS } & \text { Balance of Payments Statistics } \\ \text { BPM6 } & \text { Balance of Payments Manual, } \text { th }^{\text {th }} \text { Edition } \\ \text { CGE } & \text { Computable General Equilibrium } \\ \text { COMTRADE } & \text { Commodity Trade Statistics Database } \\ \text { FAO } & \text { Food and Agriculture Organization } \\ \text { FAOSTAT } & \text { Food and Agriculture Organization's Statistical Database } \\ \text { GDP } & \text { Gross Domestic Product } \\ \text { GFCF } & \text { Gross Fixed Capital Formation } \\ \text { GFS } & \text { Government Finance Statistics } \\ \text { GFSM } & \text { Government Finance Statistics Manual } \\ \text { GOS } & \text { Gross Operating Surplus } \\ \text { IMF } & \text { International Monetary Fund } \\ \text { IOT } & \text { Input-Output Table } \\ \text { ISIC } & \text { International Standard Industrial Classification } \\ \text { MALR } & \text { Ministry of Agriculture and Land Reclamation } \\ \text { SAM } & \text { Social Accounting Matrix } \\ \text { SNA } & \text { System of National Accounts } \\ \text { SUT } & \text { Supply-Use Table } \\ \text { TRAINS } & \text { Trade Analysis Information System }\end{array}$




\section{PREFACE}

The Central Agency for Public Mobilization and Statistics (CAPMAS) is pleased to present the first regionalized social accounting matrix (SAM) for Egypt. This SAM marks a major milestone in "localizing" development research and policy in Egypt and is expected to be most valuable for the development, implementation, and assessment of Egypt's national and local development plans, like Egypt's Sustainable Development Strategy 2030. In addition to standard SAMs, which combine many national datasets from institutions such as Central Banks, Ministries of Finance and Agriculture, and Statistical Bureaus, this regionalized SAM makes extensive use of sub-national level information such as the Economic Survey and Household Income and Expenditure Survey (HIECS) produced by CAPMAS, regional GDP estimates by the Ministry of Planning, Monitoring and Administrative Reform, and the Agricultural Bulletins with information at the Governorate level produced by the Ministry of Agriculture and Land Reclamation. With this data it becomes possible to provide a detailed, socioeconomic status update for different regions within Egypt. As such, the disaggregated SAM allows for analyzing developmental issues at regional level and to better understand the potential impacts of policy changes at the local level.

The regionalized SAM builds on the previous SAM 2010/11 built and published by CAPMAS with the support of the International Food Policy Research Institute (IFPRI), as well as the Supply and Use Tables for 2013, that were produced by CAPMAS. In addition to the regional dimension that has been added, the 2015 SAM is also more comprehensive. The Regional 2014/15 SAM for Egypt includes 62 sectors and 66 products. It also includes 13 factors of production, labor is disaggregated across rural and urban areas and into four education-based categories, capital is also disaggregated into four subcategories: crops, livestock, mining, and other; and land. Moreover, the new SAM has 105 household groups that are disaggregated by national per capita expenditure quintiles, then split into national rural farm, rural nonfarm, and urban households. Sectoral production, factor markets, and household groups are split into seven subnational regions: Greater Cairo, Delta, Alexandria, Northern Upper Egypt, Middle Upper Egypt, Southern Upper Egypt, and Suez Canal. ${ }^{1}$ In total, the regional 2015 SAM is composed of 646 rows $\times 646$ columns. $^{2}$

The regionalized SAM for Egypt for 2015 shall be accessible to all interested users online through the official websites of both CAPMAS and IFPRI. It is my hope that this new SAM will be widely used and that the results based on this SAM will help to inform policies in Egypt to improve the lives of the people.

Major-General Khairat Mohammed Barakat

President of the Central Agency for Public Mobilization and Statistics

http://www.capmas.gov.eg

\footnotetext{
${ }^{1}$ According to Ministry of Planning, Monitoring and Administrative Reform, 2015, Regional Accounts.

2 In contrast, the previous national 2010/11 SAM had only 136 row and columns. Specifically, it included 52 activities and 49 commodities, only three types of factors of production, with labor disaggregated into three categories based on skill levels; and the household sector was divided into urban and rural, and disaggregated into 10 deciles according to expenditures. All the accounts were constructed on the national level with no regional disaggregation.
} 


\section{ACKNOWLEDGEMENT}

The staff of the General Department of National Accounts at CAPMAS ${ }^{3}$ and the IFPRI team thank all those who collaborated with us in preparing for and producing this significant output. We would like to pay special tribute to Major General Khairat Mohammed Barakat, President of CAPMAS, for his continuous and on-going support to the Department's staff.

We gratefully acknowledge the financial support provided by the International Fund for Agricultural Development (IFAD) towards the SAM construction and related capacity building sessions under the Agriculture (Arab) Investment for Development Analyzer (AIDA) project, which is implemented by IFPRI.

We also wish to thank the Ministry of Agriculture and Land Reclamation (MALR) for the data they provided and the clarifications that they offered to our queries whenever needed. We also appreciate the invaluable collaboration of Mr. Kotb Salem of the Ministry of Economic Development. The continuous and on-going support of the CAPMAS' sector leaders to the staff as they constructed the SAM was gratefully received. In particular, we highly appreciate the invaluable support of Ms. Ghada Mostafa.

CAPMAS and IFPRI looks forward to receiving feedback and comments on the disaggregated SAM from those interested in economic and financial studies, especially studies that may contribute to improving and building upon this body of work. We hope that this work realizes its objective, which is to benefit economic researchers, analysts, and decision makers; and ultimately, to provide considerable added value to the work of CAPMAS, in general, and to the Department of National Accounts, in particular.

\footnotetext{
${ }^{3}$ The team at the General Department of National Accounts responsible for working on the 2015 regionalized Social Accounting Matrix for Egypt is made up of Ms. Faiza Hussein Imam, Ms. Eman Abbas Mohamed, Ms. Asmaa Samieh Abdulwahab, Ms. Naglaa Hassan Al-Soudany, Mr. Mahmoud Mohamed Al-Sadawi, Mr. Saad-Allah El-Deen Bayazied, Ms. Dalia Mohamed Moselhy, Mr. Ahmed Fathi Ahmed, and Ms. Amany Shahien Abdulghafour
} 


\section{SOCIAL ACCOUNTING MATRICES}

A national social accounting matrix (SAM) is an economy-wide data framework that captures the detailed economic structure of a country. A SAM is a square matrix in which each account is represented by a row and a column. ${ }^{4}$ Each cell reflects a payment from the column account to the row account, i.e., incomes appear along rows and expenditures along columns. Double-entry accounting requires that, for each account, total revenue (row total) equals total expenditure (column total). Table 1 shows an aggregate SAM, with verbal explanations in place of numbers.

Activities and commodities: Standard SAMs created under the Nexus project ${ }^{5}$ distinguish between "activities" (entities that carry out production) and "commodities" (representing markets for goods and non-factor services). SAM flows are valued at producer prices in activity accounts and at market prices in commodity accounts, i.e., inclusive of indirect taxes and transactions cost margins. Commodities consist of activity outputs, either exported or sold domestically, and imports. In the activity columns, payments are made to commodities (intermediate demand) and factors of production (value-added, equal to operating surplus and compensation of employees). In the commodity columns, payments are made to domestic activities, the rest of the world, and various tax accounts (for domestic and import taxes).

Government income and payments: The government in a Nexus SAM is disaggregated into a core government account and various tax collection accounts. Tax accounts are necessary since otherwise the economic interpretation of certain payments becomes ambiguous. Direct payments between the government and other domestic institutions are reserved for transfers. Payments from the government to factors are captured in the government services activity. Government consumption demand is a purchase of the output from the government services activity, which, in turn, pays labor.

Domestic nongovernment institutions: Domestic nongovernment institutions consist of households and enterprises. Enterprises earn factor incomes, reflecting their ownership of capital, and receive transfers from other institutions. Enterprise incomes are used for corporate taxes, enterprise savings, and transfers to other institutions. Unlike households, enterprises do not demand commodities. In the SAM, enterprises are an aggregation of financial and nonfinancial corporations, as defined within the System of National Accounts (SNA).

\footnotetext{
${ }^{4}$ For a lengthier discussion on SAMs, see Pyatt and Round (1985) and Reinert and Roland-Holst (1997).

${ }^{5}$ The Nexus Project is a collaboration between international organizations and national statistical agencies and research institutions to improve the quality of social accounting matrices (SAMs) used for country-level computable general equilibrium (CGE) modeling. The Nexus Project establishes common data standards, procedures and classification systems for constructing and updating national SAMs. The Nexus Project addresses the need for greater transparency and consistency in SAM construction in order to strengthen model-based research and policy analysis in developing countries. It also supports more robust cross-country comparisons of economic structure and policy. The guiding principle of the Nexus Project is that all SAM data should be traceable to its original sources and/or assumptions. Nexus SAMs are freely available online or from collaborating organizations and statistical agencies.

The Nexus Project is led by the International Food Policy Research Institute (IFPRI). Participating organizations include the Food and Agriculture Organization (FAO), the International Fund for Agricultural Development (IFAD), the European Community's Institute for Prospective Technological Studies (JRC-IPTS), the World Bank, and the United Nations University's World Institute for Development Economics Research (UNU-WIDER). Nexus SAMs are often constructed together with national statistical agencies and are regularly updated to include the most recent available data. The African Growth and Development Policy Modeling (AGRODEP) network helps disseminate Nexus SAMs to African researchers. IFPRI's participation in the Nexus Project is funded by the CGIAR Research Program (CRP) on "Policies, Institutions and Markets" (PIM). Please contact Dr. James Thurlow, IFPRI, Washington D.C. Email: j.thurlow@cgiar.org.
} 
Table 1: Standard Nexus Macro Social Accounting Matrix

\begin{tabular}{|c|c|c|c|c|c|c|c|c|c|c|}
\hline & Activities & $\begin{array}{l}\text { Commod- } \\
\text { ities }\end{array}$ & Factors & Enterprises & Households & Government & Taxes & Investment & $\begin{array}{l}\text { Rest of the } \\
\text { World }\end{array}$ & Total \\
\hline Activities & & $\begin{array}{l}\text { Marketed } \\
\text { outputs }\end{array}$ & & & $\begin{array}{c}\text { Private non- } \\
\text { marketed } \\
\text { consumption }\end{array}$ & & & & & $\begin{array}{l}\text { Activity } \\
\text { income }\end{array}$ \\
\hline $\begin{array}{l}\text { Commod- } \\
\text { ities }\end{array}$ & $\begin{array}{l}\text { Intermediate } \\
\text { demand }\end{array}$ & $\begin{array}{l}\text { Transaction } \\
\text { costs }\end{array}$ & & & $\begin{array}{c}\text { Private } \\
\text { marketed } \\
\text { consumption }\end{array}$ & $\begin{array}{l}\text { Government } \\
\text { consumption }\end{array}$ & & $\begin{array}{l}\text { Gross capital } \\
\text { formation }\end{array}$ & Exports & $\begin{array}{c}\text { Total } \\
\text { demand }\end{array}$ \\
\hline Factors & Value-added & & & & & & & & $\begin{array}{l}\text { Foreign } \\
\text { transfers to } \\
\text { factors }\end{array}$ & $\begin{array}{l}\text { Factor } \\
\text { income }\end{array}$ \\
\hline Enterprises & & & $\begin{array}{c}\text { Factor } \\
\text { income to } \\
\text { enterprises }\end{array}$ & & & $\begin{array}{l}\text { Government } \\
\text { transfers to } \\
\text { enterprises }\end{array}$ & & & $\begin{array}{l}\text { Foreign } \\
\text { transfers to } \\
\text { enterprises }\end{array}$ & $\begin{array}{l}\text { Enterprise } \\
\text { income }\end{array}$ \\
\hline Households & & & $\begin{array}{c}\text { Factor } \\
\text { income to } \\
\text { households }\end{array}$ & $\begin{array}{l}\text { Enterprise } \\
\text { transfers to } \\
\text { households }\end{array}$ & & $\begin{array}{l}\text { Government } \\
\text { transfers to } \\
\text { households }\end{array}$ & & & $\begin{array}{l}\text { Foreign } \\
\text { transfers to } \\
\text { households }\end{array}$ & $\begin{array}{l}\text { Household } \\
\text { income }\end{array}$ \\
\hline Taxes & $\begin{array}{l}\text { Taxes on } \\
\text { producers }\end{array}$ & $\begin{array}{l}\text { Taxes on } \\
\text { products }\end{array}$ & Factor taxes & $\begin{array}{l}\text { Corporate } \\
\text { taxes }\end{array}$ & $\begin{array}{l}\text { Household } \\
\text { taxes }\end{array}$ & & & & & $\begin{array}{c}\text { Tax } \\
\text { income }\end{array}$ \\
\hline Government & & & & $\begin{array}{l}\text { Enterprise } \\
\text { transfers to } \\
\text { government }\end{array}$ & $\begin{array}{l}\text { Household } \\
\text { transfers to } \\
\text { government }\end{array}$ & & $\begin{array}{c}\text { Tax revenues } \\
\text { paid to } \\
\text { government }\end{array}$ & & $\begin{array}{c}\text { Foreign } \\
\text { transfers to } \\
\text { government }\end{array}$ & $\begin{array}{l}\text { Government } \\
\text { income }\end{array}$ \\
\hline Savings & & & & $\begin{array}{l}\text { Enterprise } \\
\text { savings }\end{array}$ & $\begin{array}{l}\text { Household } \\
\text { savings }\end{array}$ & $\begin{array}{l}\text { Government } \\
\text { savings }\end{array}$ & & & $\begin{array}{l}\text { Foreign } \\
\text { savings }\end{array}$ & Savings \\
\hline $\begin{array}{l}\text { Rest of the } \\
\text { World }\end{array}$ & & Imports & $\begin{array}{l}\text { Factor } \\
\text { payments } \\
\text { abroad }\end{array}$ & $\begin{array}{l}\text { Enterprise } \\
\text { payments } \\
\text { abroad }\end{array}$ & $\begin{array}{l}\text { Household } \\
\text { payments } \\
\text { abroad }\end{array}$ & $\begin{array}{c}\text { Government } \\
\text { payments } \\
\text { abroad }\end{array}$ & & & & $\begin{array}{l}\text { Foreign } \\
\text { exchange } \\
\text { outflow }\end{array}$ \\
\hline Total & $\begin{array}{c}\text { Activity } \\
\text { expenditures }\end{array}$ & $\begin{array}{l}\text { Total } \\
\text { supply }\end{array}$ & $\begin{array}{c}\text { Factor } \\
\text { expenditures }\end{array}$ & $\begin{array}{c}\text { Enterprise } \\
\text { expenditures }\end{array}$ & $\begin{array}{c}\text { Household } \\
\text { expenditures }\end{array}$ & $\begin{array}{l}\text { Government } \\
\text { expenditures }\end{array}$ & $\begin{array}{c}\text { Tax } \\
\text { payments }\end{array}$ & Investment & $\begin{array}{l}\text { Foreign } \\
\text { exchange } \\
\text { inflow }\end{array}$ & \\
\hline
\end{tabular}


Household consumption: Nexus SAMs distinguish between home (own) consumption of activities and marketed consumption of commodities by households. Home consumption, which appears in the SAM as payments from household accounts to activity accounts, is valued at producer prices, i.e., without marketing margins and sales taxes that may be levied on marketed commodities. Final household consumption of marketed commodities appears as payments from household accounts to commodity accounts, valued at consumer prices, including marketing margins and taxes.

\section{STANDARD NEXUS SOCIAL ACCOUNTING MATRIX ACCOUNTS}

Activities and commodities: Standard SAMs created under the Nexus project separate domestic production into 86 activities, as shown in Table 2. Each activity represents a group of industries from the International Standard Industrial Classification system (ISIC Revision 4) (UNDESA 2008). The 4-digit ISIC codes corresponding to each SAM activity are shown in Table A1 in the Appendix. ${ }^{6}$ Agricultural activities are further disaggregated using FAO's classification system, as shown in Table A2 in the Appendix. Information on production technologies comes from national input-output tables (IOT) or supply-use tables (SUT). Activities and commodities have a one-to-one mapping based on a concordance between ISIC industries and Harmonized System products (HS Version 2007). ${ }^{7}$ Some countries' national accounts capture how activities can produce multiple commodities - this information is discarded in Nexus SAMs. (See the description of Egypt's SAM in Section 5.)

Factors of production: Nexus SAMs separate factors into three broad categories: labor, land, and capital. Labor is further disaggregated across rural and urban areas and into four education-based categories, as shown in Table 3. Nexus SAMs follow official definitions of "rural" and "urban" areas, which may vary between countries, but are consistent with the definitions used in national and international statistics. ${ }^{8}$ There is greater consistency in education categories across countries since these are based on the number of years of schooling that workers report having completed (see the notes provided in Table 3). Information on total labor value-added as a share of sectoral gross domestic product (GDP) is drawn from national IOTs or SUTs. This is disaggregated across labor subcategories using wage and salary data as well as imputed earnings for unpaid family members as reported in household and labor force surveys (see Section 5).

Capital is disaggregated into four subcategories: crops, livestock, mining, and other. Crop capital in each crop-based agricultural activity is the portion of gross operating surplus (GOS) and mixed income that is reported in national IOTs or SUTS and that is not assigned to either labor or land factors, i.e., it is a residual. Livestock capital is the total GOS generated in the three livestock activities, i.e., cattle, poultry, and other livestock, while mining capital is the total GOS earned in the four mining activities, i.e., coal and lignite, crude oil, natural gas, and other mining. Crop and livestock capital are separated from mining and other capital, since, in Nexus SAMs, the former are paid directly to households, while the latter are paid to enterprises. Mining capital is separated from "other" capital because its earnings are often subject to mining-specific taxes and royalties, and they are more likely to be repatriated to foreign-based companies.

\footnotetext{
${ }^{6}$ Mapping between Nexus SAM activities and ISIC Revision 3.1 codes (UNDESA 2002) are available upon request.

${ }^{7}$ The concordance between Nexus SAM commodities and HS 2007 codes are available upon request.

${ }^{8}$ Rural and urban status is based on workers' reported place of residence, rather than their place of work. This is consistent with most household and labor force surveys, and hence with most official statistics.
} 
Table 2. Activities and Commodities in the Standard Nexus Social Accounting Matrix

\begin{tabular}{|c|c|c|c|c|c|}
\hline Code & Description & Code & Description & Code & Description \\
\hline maiz & Maize & eggs & Eggs & clth & Clothing \\
\hline sorg & Sorghum and millet & smlr & Small ruminants & leat & Leather and footwear \\
\hline rice & Rice & oliv & Other livestock & wood & Wood products \\
\hline whea & Wheat and barley & fore & Forestry & papr & Paper products and publishing \\
\hline ocer & Other cereals & aqua & Aquaculture & petr & Petroleum products \\
\hline puls & Pulses & fish & Capture fisheries & fert & Fertilizers and herbicides \\
\hline gnut & Groundnuts & coal & Coal and lignite & chem & Other chemicals \\
\hline oils & Other oilseeds & coil & Crude oil & nmet & Non-metal minerals \\
\hline cass & Cassava & ngas & Natural gas & metl & Metals and metal products \\
\hline ipot & Irish potatoes & omin & Other mining & mach & Machinery \& other equipment \\
\hline spot & Sweet potatoes & meat & Meat processing & equi & Electrical equipment \\
\hline root & Other roots & fsea & Fish \& seafood processing & vehi & ansport equipment \\
\hline leaf & Leafy vegetables & dair & Dairy & oman & Other manufacturing \\
\hline vege & Other vegetables & fveg & Fruit \& vegetable processing & elec & Electricity, gas and steam \\
\hline sugr & Sugarcane & foil & Fats and oils & watr & Water supply and sewage \\
\hline toba & Tobacco & $\mathrm{mmll}$ & Maize milling & cons & Construction \\
\hline cott & Cotton and fibres & smll & Sorghum and millet milling & trad & Wholesale and retail trade \\
\hline nuts & Nuts & rmll & Rice milling & $\operatorname{tran}$ & Transportation and storage \\
\hline bana & Bananas \& plantains & wmll & Wheat and barley milling & hotl & Accommodation \\
\hline frui & Other fruits & gmll & Other grain milling & rest & Restaurants and food services \\
\hline teal & Leaf tea & sref & Sugar refining & comm & Information \& communication \\
\hline coff & Coffee & pcof & Coffee processing & fsrv & Finance and insurance \\
\hline coco & Cocoa & ptea & Tea processing & real & Real estate activities \\
\hline flwr & Cut flowers & food & Other foods & bsrv & Business services \\
\hline rubb & Rubber & feed & Animal feed & padm & Public administration \\
\hline ocrp & Other crops & beve & Beverages & educ & Education \\
\hline catt & Cattle & ptob & Tobacco processing & heal & Health and social work \\
\hline milk & Raw milk & yarn & Cotton yarn & osrv & Other services \\
\hline poul & Poultry & text & Textiles & & \\
\hline
\end{tabular}

Table 3. Factors in the Standard Nexus Social Accounting Matrix

\begin{tabular}{cll}
\hline Code & \multicolumn{1}{c}{ Description } & \multicolumn{1}{c}{ Notes } \\
\hline $\begin{array}{c}\text { Labor } \\
\text { flab-rn }\end{array}$ & Labor - rural uneducated & 0-6 years of formal schooling \\
flab-rp & Labor - rural primary & $7-11$ years of formal schooling \\
flab-rs & Labor - rural secondary & $12+$ years of formal schooling and/or incomplete tertiary education \\
flab-rt & Labor - rural tertiary & Completed tertiary education (e.g., degree, certificate, diploma) \\
flab-un & Labor - urban uneducated & $0-6$ years of formal schooling \\
flab-up & Labor - urban primary & $7-11$ years of formal schooling \\
flab-us & Labor - urban secondary & $12+$ years of formal schooling and/or incomplete tertiary education \\
flab-ut & Labor - urban tertiary & Completed tertiary education (e.g., degree, certificate, diploma) \\
Land & & \\
flnd & Land - agricultural crops & Harvested crop land \\
Capital & & \\
fcap-c & Capital - crops & For agricultural crops (e.g., tractors, irrigation infrastructure) \\
fcap-I & Capital - livestock & For livestock (e.g., live animals, paddocks, beehives) \\
fcap-m & Capital - mining & For mining (e.g., mineral resources, mining equipment) \\
fcap-o & Capital - other & For all other sectors, including forestry and fisheries \\
\hline
\end{tabular}


Households: Nexus SAMs separate national populations into 15 representative household groups, as shown in Table 4. As with labor, the SAM distinguishes between rural and urban households using a country's official definition of these areas. Rural households are further disaggregated into households that earn crop and/or livestock incomes, i.e., farm households, and those that do not earn incomes from either source, i.e., nonfarm households.

Table 4. Household Types in the Standard Nexus Social Accounting Matrix

\begin{tabular}{|c|c|c|}
\hline Code & Description & Notes \\
\hline hhd-f1 & Rural farm - quintile 1 & \multirow{5}{*}{$\begin{array}{l}\text { Rural households with crop and/or livestock incomes separated } \\
\text { into national per capita expenditure quintiles }\end{array}$} \\
\hline hhd-f2 & Rural farm - quintile 2 & \\
\hline hhd-f3 & Rural farm - quintile 3 & \\
\hline hhd-f4 & Rural farm - quintile 4 & \\
\hline hhd-f5 & Rural farm - quintile 5 & \\
\hline hhd-n1 & Rural nonfarm - quintile 1 & \multirow{5}{*}{$\begin{array}{l}\text { Rural households without crop and/or livestock incomes } \\
\text { separated into national per capita expenditure quintiles }\end{array}$} \\
\hline hhd-n2 & Rural nonfarm - quintile 2 & \\
\hline hhd-n3 & Rural nonfarm - quintile 3 & \\
\hline hhd-n4 & Rural nonfarm - quintile 4 & \\
\hline hhd-n5 & Rural nonfarm - quintile 5 & \\
\hline hhd-u1 & Urban - quintile 1 & \multirow{5}{*}{$\begin{array}{l}\text { Urban households with or without crop and/or livestock incomes } \\
\text { separated into national per capita expenditure quintiles }\end{array}$} \\
\hline hhd-u2 & Urban - quintile 2 & \\
\hline hhd-u3 & Urban - quintile 3 & \\
\hline hhd-u4 & Urban - quintile 4 & \\
\hline hhd-u5 & Urban - quintile 5 & \\
\hline
\end{tabular}

Households are further disaggregated into per capita expenditure quintiles. Quintiles are defined at the national level, meaning that rural and urban quintiles are comparable and the combined population of each quintile is a fifth of the national population. Per capita expenditure groups are not adjusted for adult-equivalency and include all consumption expenditure items reported in national household surveys. The latter implies that the definition of quintiles in Nexus SAMs may deviate slightly from those based on poverty-oriented consumption measures, which may exclude "non-essential" nonagricultural expenditure items (e.g., airplane tickets or gambling).

Other accounts: The remaining accounts in the Nexus SAMs are shown in Table 5. These include the transaction costs of moving goods between producers, domestic markets, and national borders, as well as the various indirect taxes imposed on marketed commodities. 
Table 5. Accounts in the Standard Nexus Social Accounting Matrix

\begin{tabular}{|c|c|c|}
\hline Code & Description & Notes \\
\hline a & Activities & See Table 2 for the list of activity accounts \\
\hline c_ & Commodities & See Table 2 for the list of commodity accounts \\
\hline$f$ & Factors & See Table 3 for the list of factor accounts \\
\hline h_ & Households & See Table 4 for the list of household accounts \\
\hline $\operatorname{trc}$ & Transaction costs & From moving goods between producers, markets, and/or borders \\
\hline ent & Enterprises & Financial and non-financial corporations \\
\hline gov & Government & Government as an institution, not as a producing activity \\
\hline atax & Taxes - activity & Indirect taxes on producers \\
\hline dtax & Taxes - direct & Direct taxes on enterprises and households \\
\hline etax & Taxes - export & Indirect taxes on exports \\
\hline $\mathrm{ftax}$ & Taxes - factor & Direct taxes on factor incomes \\
\hline $\operatorname{mtax}$ & Taxes - import & Indirect taxes on imports (import duties) \\
\hline stax & Taxes - sales & Indirect taxes on domestic sales (VAT, GST and excise duty) \\
\hline$s-i$ & Savings-investment & Investment is gross fixed capital formation \\
\hline dstk & Change in stocks & Inventory accumulation or depletion \\
\hline row & Rest of world & All foreign countries and economies \\
\hline total & Total & Row and column totals \\
\hline
\end{tabular}

Sex-disaggregated and regional accounts: Standard Nexus SAMs often include variants with more detailed accounts. Each SAM variant aggregates back to the Standard Nexus SAM (note that the 86sector national SAM is labeled "V86N"). It should be noted that adding more detail to a SAM often requires greater use of assumptions and proxy variables for distributing incomes and expenditures, and it can stretch the representativeness of survey data. The Nexus Project therefore publishes its national SAMs separately from its regional and gendered SAMs.

Gendered Nexus SAMs (v86G) disaggregate each labor category in Table 3 into male and female workers. Land, livestock, and agricultural capital are disaggregated based on the gender of the de jure household head whose household reports incomes from these factors. Each household group in Table 4 are disaggregated according to whether they have a male or female household head. Accounts that change between the Standard and Gendered Nexus SAMs are shown in Table 6.

Table 6. Gendered Accounts in the Nexus Social Accounting Matrix

\begin{tabular}{ll}
\hline \multicolumn{1}{c}{ Code } & \multicolumn{1}{c}{ Description } \\
\hline flab-_-m & Male labor (see Table 3 for further codes) \\
flab-__f & Female labor (see Table 3 for further codes) \\
\hline flnd-m & Crop land owned by male-headed households \\
flnd-f & Crop land owned by female-headed households \\
\hline fcap-c-m & Crop capital owned by male-headed households \\
fcap-c-f & Crop capital owned by female-headed households \\
\hline fcap-l-m & Livestock capital owned by male-headed households \\
fcap-l-f & Livestock capital owned by female-headed households \\
\hline hhd-_-m & Male headed households (see Table 4 for further codes) \\
hhd-_-f & Female headed households (see Table 4 for further codes) \\
\hline
\end{tabular}

Regional Nexus SAMs (V70R) aggregate the 86 activities into 70 activities, which are in turn disaggregated by subnational region. A mapping between N86 and N70 can be found in Table A3 in the Appendix. In some cases, only certain activities, such as agriculture, are regionally disaggregated due to data limitations. All factors and households are defined by region, except for mining and 
"other" capital. Accounts that change between the Standard and Regional Nexus SAMs are shown in Table 7.

Table 7. Regional Accounts in the Nexus Social Accounting Matrix

\begin{tabular}{|c|c|}
\hline Code & Description \\
\hline$-r_{-}$ & Activities by numbered region of operation (see Table 1 for further codes) \\
\hline flab-_-r & Labor by numbered region of employment (see Table 2 for further codes) \\
\hline flnd- $r_{-}$ & Crop land by numbered region \\
\hline fcap-c- $r_{-}$ & Crop capital by numbered region of use \\
\hline fcap-l- $r_{-}$ & Livestock capital by numbered region of use \\
\hline hhd-_- $r$ & Households by numbered region (see Table 4 for further codes) \\
\hline
\end{tabular}

Country-specific deviations from the standard structure: The SAM structure presented above represents the minimum level of disaggregation required of a Nexus SAM. Some countries have more disaggregated accounts, but these can always be aggregated to the Standard Nexus accounts. Section 5 documents any extensions to the Standard Nexus SAM structure that were used in developing the SAM for Egypt.

\section{NEXUS SOCIAL ACCOUNTING MATRIX ENTRIES AND GENERAL DATA SOURCES}

The previous section outlined the broad structure of a Nexus SAM, including its standardized classification of accounts. This section describes the information included in each row and column entry in the SAM. One advantage of Nexus SAMs is that the Macro SAM has a common classification or definition of cell entries. This section describes each of the blocks of cells in the Macro SAM following the numbered sequence shown in Table 8.

The Macro SAMs are compiled using three key data sources. First, the International Monetary Fund's (IMF) Government Finance Statistics (GFS) database provides detailed information on government revenues and expenditures and follows a standardized accounting framework. Nexus SAMs use the 2014 GFS Manual (GFSM) (IMF 2014b) - a mapping between GFSM codes and macro SAM accounts can be found in Table A4 in the Appendix. Second, the IMF maintains detailed Balance of Payments Statistics (BOPS) (IMF 2014a). Nexus SAMs use the sixth BOPS Manual (BPM) - a mapping between BPM 6 codes and macro SAM accounts can be found in Table A5 in the Appendix. The conversion from US dollars to local currency uses the official exchange rate, as reported in the World Development Indicators (World Bank 2015). Third, countries maintain their own national accounts that include production and expenditure-based GDP estimates. To the extent possible, the Nexus SAMs, like most countries, follow the United Nation's System of National Accounts (SNA) (UN 2009). 
Table 8: Numbered Entries in a Standard Nexus Social Accounting Matrix

\begin{tabular}{|c|c|c|c|c|c|c|c|c|c|}
\hline $\begin{array}{l}\text { Commod- } \\
\text { ities }\end{array}$ & 1 & 5 & & & 18 & 23 & & 29 & 31 \\
\hline Factors & 2 & & & & & & & & 32 \\
\hline Enterprises & & & 8 & & & 24 & & & 33 \\
\hline Government & & & & 14 & 20 & & 28 & & 35 \\
\hline Savings & & & & 15 & 21 & 26 & & 30 & 36 \\
\hline $\begin{array}{l}\text { Rest of the } \\
\text { World }\end{array}$ & & 7 & 11 & 16 & 22 & 27 & & & \\
\hline
\end{tabular}




\section{Intermediate demand}

\section{(Commodities | Activities)}

Definition: Intermediate demand includes payments by activities for the commodities used as non-factor inputs in production processes. For example, payments by the maize activity to the chemical commodity for the fertilizer inputs used to grow maize.

Estimation: Intermediate demand for each activity is estimated in three steps. First, the ratio of total intermediate demand to total value-added in each activity is derived from national IOT/SUTs and, where available, updated using more recent national accounts and/or agricultural and industrial survey data. Second, this ratio is used to derive the absolute level of total intermediate demand based on the estimated level of activity value-added (see Entry 2 below). Third, total intermediate payments are disaggregated across individual commodities using shares derived from national IOT/SUTs. Note that IOT/SUTs are usually only updated when national statistical agencies rebase national accounts. The quality or accuracy of intermediate input coefficients therefore declines over time until such time as the underlying IOT/SUTs are updated. The description of each SAM in Section 5 indicates the IOT/SUT's benchmark year.

\section{Value-added}

(Factors | Activities)

Definition: Value-added is the returns earned by factors during the production process, such as labor wages and salaries, land rents, and capital profits. Land and capital includes gross operating surplus (GOS), part of which may be reported as "mixed income" in national accounts or IOT/SUTs.

Estimation: Total value-added by activity is estimated in two steps. First, national accounts report the level of gross domestic product (GDP measured in basic prices) for aggregate sectors and these are assigned to groups of SAM activities. Second, aggregate GDP estimates are disaggregated to the level of the SAM activities using information on sub-sectoral production from sources beyond national accounts. The value of activity level agricultural production is estimated using production quantity and producer price data from national Ministries of Agriculture or from the FAO's FAOSTAT database (FAO 2015). Total value-added in each agricultural sector is estimated by multiplying the ratio of GDP to gross output (derived from IOT/SUTs) by the estimated value of activity gross output. Similarly, information on activity-level industrial production is derived from manufacturing or industrial surveys.

Labor value added is disaggregated across the worker categories in Table 3 using national household and/or labor force survey data. ${ }^{9}$ Workers in these surveys report their sector and location of employment, their remuneration levels, and their education levels. Earnings from farm and non-farm enterprises are usually reported at the household level, and these are assigned to individual household members based on their reported employment status and sector of employment. It is assumed that paid and unpaid family members earn equal shares of household enterprise incomes (net of input costs).

\section{Taxes on producers}

(Taxes | Activities)

Definition: Net taxes on production (or net subsidies if SAM value is negative).

Estimation: The total value of activity taxes (atax) is taken from the IMF's GFS and includes "taxes on payroll and workforce" (GFSM code 112). This is disaggregated across activities using information from national tax authorities and/or from the IOT/SUT. For the latter, tax rates are

\footnotetext{
${ }^{9}$ The national household surveys used to build Nexus SAMs are often the same as the surveys used to estimate poverty rates or the weights for the consumer price index. These surveys are similar to the World Bank's Living Conditions Monitoring Surveys (LCMS).
} 
derived from the IOT/SUT and then applied to the sectoral value of GDP and intermediate payments (see Entries 1 and 2). This provides an initial estimate of net activity tax payments, which are then scaled to match the total value of activity tax collections.

\section{Marketed output}

(Activities | Commodities)

Definition: Value of domestically produced goods and services that are supplied to markets, either for domestic use or for export. Marketed output is net non-marketed or home produced and consumed goods and services (see Entry 18).

Estimation: This is a residual balancing item for activities. The value of gross output less the value of non-marketed consumption is paid from each activity to its corresponding commodity, thereby balancing activity rows and columns.

\section{Transaction costs}

\section{(Commodities | Commodities)}

Definition: Trade and transport costs associated with moving goods between producers, markets and national borders, either for domestic, import or export trade. For example, exporters incur transport fees when moving goods from their factories to the national border, whereas importers incur fees when delivering goods to domestic markets.

Estimation: There are two approaches to estimating transaction costs in Nexus SAMs. First, margin payments as a share of total demand are estimated using past IOT/SUTs. These rates are then applied to total demand estimates in the SAM to derive new transaction costs. Second, margins are estimated by the gap between producer and market prices, net of indirect taxes, using price data provided by national statistical agencies. The first approach is preferred and is the one typically used for Nexus SAMs (see detailed description of each SAM's data sources for information on which approach was used). Finally, transaction cost margins generate income for trade and/or transport activities.

\section{Taxes on products}

\section{(Taxes | Commodities)}

Definition: All indirect taxes imposed on goods and services (or net subsidies if SAM value is negative).

Estimation: Nexus SAMs separate taxes on products into three categories: sales taxes (stax), export taxes (etax), and import tariffs (mtax) (see Table 4). The total value of tax collections is taken from the IMF's GFS. Sales taxes are "taxes on goods and services" (GFSM code 114), which is a summation of various tax instruments, most importantly value-added taxes (GFSM 11411), sales taxes (GFSM 11412), and excise duties (GFSM 1142). Import tariffs (mtax) are "taxes on international trade and transactions" (GFSM 115), excluding "taxes on exports" (GFSM 1152), which are assigned to export taxes in the SAM.

Tax revenues are disaggregated across commodities using national tax authority data and/or tax rates estimated from the IOT/SUT. If the IOT/SUT is outdated, then weighted import tariff rates are taken from the United Nations Conference on Trade and Development's Trade Analysis and Information System (TRAINS) (UNCTAD 2015). Tax rates are applied to the level of domestic sales, imports or exports (see Entries 7 and 32). This provides an initial estimate of commodity level tax payments, which are then scaled to match the total value of each tax revenue category, as estimated above.

\section{Imports}

\section{(Rest of World | Commodities)}

Definition: Value of goods and services imported from abroad, less the cost of carriage, insurance and freight. 
Estimation: The total value of imports is taken from national accounts, and this is then disaggregated into total goods and total services using current account data from the IMF's BOPS (i.e., BPM6 codes BMG for "goods, debit" and BMS for "services, debit"). BOPS provides detailed information on services imports by commodity and this is used to assign imports to service commodities in the SAM (see Table A5 in the appendix). Goods imports are disaggregated across commodities using 6-digit HS gross import flows from the United Nations Commodity Trade Statistics (COMTRADE) database (UNSD 2015).

\section{Factor income to enterprises}

\section{(Enterprises | Factors)}

Definition: Mining and "other" capital payments to enterprises, after paying factor taxes and making transfers to the rest of the world (see Entries 10 and 11). These payments equal gross operating surplus, which includes the value of consumption of fixed capital during the production process.

Estimation: This is a residual balancing item for the mining and other capital accounts. Total capital income less capital taxes and foreign transfers is paid to the enterprise account, thereby balancing mining and other capitals' rows and columns.

\section{Factor income to households}

(Households | Factors)

Definition: Labor, land and agricultural capital payments to households, after paying factor taxes and making transfers to the rest of the world (see Entries 10 and 11). These payments equal compensation to workers and returns to land and agricultural capital.

Estimation: This is a residual balancing item for labor, land and agricultural capital accounts (i.e., crop and livestock capital). Total factor incomes less factor taxes and foreign transfers are paid to individual household accounts, thereby balancing these factors' rows and columns. Labor payments to households are disaggregated across household and labor categories using information from national household or labor force surveys (see Entry 2 on treatment on workers' shares of household enterprise incomes). Land and agricultural capital payments to households are disaggregated using survey households' reported incomes from agricultural crops and livestock.

10.Factor taxes

\section{(Taxes | Factors)}

Definition: Direct taxes paid by mining and "other" capital to the government.

Estimation: The value of capital tax collections is taken from the IMF's GFS. Factor taxes are "taxes on property" (GFSM code 113), which is a summation of various taxes, including wealth and estate taxes and capital levies.

\section{Factor payments abroad}

(Rest of World | Factors)

Definition: Labor, land and capital incomes paid to foreign households or enterprises. For example, workers belonging to foreign households may earn some or all of their labor incomes in domestic industries and this income may be repatriated back to these workers' home countries. Similarly, some profits generated by foreign-owned mining companies may be repatriated to company headquarters in another country.

Estimation: Factor transfers to the rest of the world are from the IMF's BOPS. Labor transfers are "compensation of employees, debit" (BPM6 code BMIPCE). Capital transfers are "investment income, debit" (BPM6 BMIPI), which includes, amongst others, payments on equity and investment funds to foreign investors. 


\section{Enterprise transfers to households}

(Households | Enterprises)

Definition: Indirect capital payments by enterprises to households, after paying corporate taxes and saving and making transfers to government and the rest of the world (see Entries 13, 14, 15 and 16). This includes indirect gross operating surplus paid from the earnings of household nonfarm enterprises.

Estimation: This is a residual balancing item for the enterprise account. Total enterprise income less taxes and transfers is paid to households, thereby balancing the enterprise row and column. Enterprise earnings are paid to households based on households' earnings from nonfarm enterprises, dividends and private pension funds as reported in national household surveys.

\section{Corporate taxes}

(Taxes | Enterprises)

Definition: Corporate and other direct taxes paid by enterprises to the government.

Estimation: The total value of taxes collected from enterprises is taken from the IMF's GFS. This includes taxes "payable by corporations and other enterprises" (GFSM code 1112) and "other taxes on income, profits, and capital gains" (GFSM 1113).

\section{Enterprise transfers to government}

(Government | Enterprises)

Definition: Transfers from enterprises to governments, other than direct tax payments (see Entry 13). For example, domestic banks may provide loans to the government, or parastatal enterprises may pay dividends or repay loans to the general government. Enterprises may also contribute to public social welfare schemes on behalf of their employees.

Estimation: Transfers received by the government from financial and non-financial corporations are taken from the IMF's GFS. This is "property income" (GFSM code 141), which includes, amongst others, interest and dividend payments and payments for rented public property. Transfers from enterprises also include "other taxes" (GFSM 116), which are either paid by business or are unidentifiable. Finally, enterprises include employer contributions to social security (GFSM 1212) and other social schemes (GFSM 1222).

\section{Enterprise savings}

\section{(Savings | Enterprises)}

Definition: Domestic private savings by enterprises. This includes reinvested earnings as well as the value of the consumption of fixed capital (i.e., provision for capital depreciation).

Estimation: Total domestic private savings is back-calculated by subtracting public and foreign savings from the value of gross capital formation (see Entries 21, 26, 29 and 36). Unfortunately, few developing countries have the detailed national accounts data needed to disaggregate domestic private savings across enterprises and households. Accordingly, in the absence of detailed information, the Nexus SAMs assume that enterprises and households have similar savings rates, after enterprises have subtracted their allowance for the depreciation of working capital.

\section{Enterprise payments abroad}

\section{(Rest of World | Enterprises)}

Definition: Secondary income transfers from domestic financial and non-financial enterprises to the rest of the world.

Estimation: The value of enterprise foreign payments comes from the IMF's BOPS. This includes "other transfers, debit" (BPM6 code BMISOOT). 


\section{Private non-marketed consumption}

\section{(Activities | Households)}

Definition: Activity output that is both produced and consumed within the household, i.e., "own" or "home" consumption.

Estimation: Non-marketed consumption is estimated in three steps. First, the share of total private consumption for each Nexus SAM commodity is estimated using aggregate private consumption from national accounts and commodity-level consumption from national household surveys. Second, the share of home consumption in total consumption of each commodity is estimated using the household surveys, and this share of then used to separate total commodity consumption into marketed and non-marketed components. Third, home consumption is disaggregated across household groups using household survey data. Home consumption is defined as any products not purchased in markets, including the consumption of both homeproduced products and products received "in-kind" from other households (i.e., without monetary payment).

18.Private marketed consumption

(Commodities | Households)

Definition: Commodities that are purchased in markets and consumed by households.

Estimation: Marketed consumption is estimated in three steps. First, the share of total private consumption for each Nexus SAM commodity is estimated using aggregate private consumption from national accounts and commodity-level consumption from national household surveys. Second, the share of home consumption in total consumption of each commodity is estimated using the household surveys, and this share of then used to separate total commodity consumption into marketed and non-marketed components. Third, marketed consumption is disaggregated across household groups using household survey data. Marketed consumption is defined as any products purchased in markets, i.e., not home produced or received "in-kind" from other households.

\section{Household taxes}

(Taxes | Households)

Definition: Direct income or personal taxes paid by households. For example, households often "pay as you earn" (PAYE) taxes to the government based on their wages and salaries.

Estimation: Total tax collection is taken from the IMF's GFS. It includes taxes on income, profits and capital gains that are "payable by individuals" (GFSM code 1111). This is disaggregated across the household groups in the Nexus SAMs using personal income tax rates reported by households in the national household survey. If tax data if not available or is poorly captured in the survey, then incomes from secondary and tertiary educated labor is used as a proxy for disaggregating total direct tax collections (see Table 3).

\section{Household transfers to government (Government | Households)}

Definition: Payments by household to the government other than for direct taxes (see Entry 19). For example, households may contribute to public social welfare schemes, including retirement and healthcare funds.

Estimation: The total value of transfers is taken from the IMF's GFS. This is social security and other social contributions, including payments by employees (GFSM codes 1211 and 1221), selfemployed and unemployed people (GFSM 1213), and unallocable and imputed contributions (GFSM 1214 and 1223). Household transfers to government also include various other revenue sources, including from sales of goods and services (GFSM 142), and fines penalties and forfeits (GFSM 143). 
Definition: Domestic private savings by households.

Estimation: Total domestic private savings is back-calculated by subtracting public and foreign savings from the value of gross capital formation (see Entries 21, 26, 29 and 36). Unfortunately, few developing countries have the detailed national accounts data needed to disaggregate domestic private savings across enterprises and households. Accordingly, in the absence of detailed information, the Nexus SAMs assume that enterprises and households have similar savings rates, after enterprises have subtracted their allowance for the depreciation of working capital. Household savings are then disaggregated across household groups in the SAM using information from national household surveys. Although survey households often report the value of deposits made into bank accounts or the amount of savings during the year, including private pension contributions, this information is often poorly captured. In such cases, proxy indicators are derived from household earnings from enterprises and incomes from higher educated labor.

\section{Household payments abroad}

(Rest of World | Households)

Definition: Secondary income transfers from households to the rest of the world.

Estimation: The value of household foreign payments comes from the IMF's BOPS. This includes "personal transfers, debit" (BPM6 code BMISOPT). Transfers are disaggregated across household groups in the SAM using information from national household surveys that capture the amount of remittances households sent abroad.

\section{Government consumption}

\section{(Commodities | Government)}

Definition: Government recurrent spending on goods and services. Public consumption demand by the government institution is the primary source of demand for services produced by government activities, which consist of public administration, education, and health and social work.

Estimation: The total value of government consumption is taken from a country's national accounts data. This is cross-checked against recurrent expenditures in the IMF's GFS, which reports government's "compensation of employees" (GFSM code 21), "use of goods and services" (GFSM 22), and "consumption of fixed capital" (GFSM 23). Total consumption is disaggregated across commodities using budget shares derived from the IOT/SUT, and then adjusted to reflect changes in the composition of supply of public administration, education, and health and social work services.

\section{Government transfers to enterprises}

(Enterprises | Government)

Definition: Transfers from the government to enterprises. For example, the government may pay interest or repay the principal on a loan from a domestic bank, or the government may lend money to parastatal companies.

Estimation: Transfers paid by the government to financial and non-financial corporations are taken from the IMF's GFS. This is interest payments to nongovernment residents (GFSM code 242 ), subsidies to public corporations and private enterprises (GFSM 25) and "other expenses" (GFSM 28). The latter includes property expenses like dividend and rental payments.

\section{Government transfers to households (Households | Government)}

Definition: Payments by the government to households. For example, governments may pay households from a public pension or cash transfer scheme. 
Estimation: The total value of transfers is taken from the IMF's GFS. This is social benefits (GFSM code 27), which includes social security, social assistance, and other employment-related social benefits, each of which may be paid in cash or in-kind.

\section{Government savings}

(Savings | Government)

Definition: Recurrent fiscal surplus for the government (of deficit if cell entry is negative). Note that this is the difference between revenues and recurrent expenditures, i.e., before public capital investment. Recurrent expenditures include public consumption spending (see Entry 25) and transfers to domestic and foreign institutions (see Entries 24, 25 and 27).

Estimation: This is the residual balancing item for the government account, although it crosschecked against the difference between total revenues and total recurrent expenses in the IMF's GFS (GFSM codes 1 and 2). Any deviation from GFS data is due to the Nexus SAM giving preference to statistics from national accounts (for indirect tax collections and government consumption spending, see Entries 3, 6 and 23) and to the IMF's BOP database (for foreign transfers, see Entries 27 and 35). ${ }^{10}$

\section{Government payments abroad}

(Rest of World| Government)

Definition: Transfers from the government to the rest of the world. For example, government may provide foreign aid to other countries, or must pay interest or repay loans to foreign governments and financial enterprises.

Estimation: The value of government foreign payments comes from the IMF's BOPS, and is crosschecked against the IMF's GFS. BOPS-based payments include "general government transfers, debit" under secondary income (BPM6 code BMISG). GFS-based payments include interest payments to nonresidents (GFSM code 241), and grants paid to foreign governments and international organizations (GFSM 26).

\section{Tax revenues paid to government (Government | Taxes)}

Definition: Revenues transferred from individual tax accounts to the government account.

Estimation: This is a residual balancing item for the tax accounts in the SAM. The distinction between taxes and the government account allows the SAM to disaggregate indirect taxes on commodities, i.e., sales taxes, export taxes, and import tariffs (see Entry 6).

\section{Gross capital formation}

(Commodities | Investment)

Definition: Combination of gross fixed capital formation (GFCF) and changes in stocks or inventories. GFCF is the spending on commodities involved during the investment in capital stock. For example, investment typically involves the purchase of machinery, vehicles and equipment, as well as payments for constructing new factories and storage facilities. Changes in stocks occur when businesses carry-over stock for sale in subsequent years, or when they sell products in the current year that were produced in previous years. Positive values in the SAM indicate an accumulation of stocks and negative values indicate a depletion of stocks. Finally, note that the Nexus SAMs combine private, public and foreign investment, just as they combine private, public and foreign savings (see Entries 15, 21 and 26).

Estimation: The Nexus SAMs distinguish between GFCF (s-i) and changes in stocks (dstk). SAM entries are determined in two steps. First, the total value of GFCF and stock changes are taken

${ }^{10}$ The value of the fiscal deficit in the macro-SAM differs slightly from that published in the Ministry of Finance's financial bulletin. This is because the Nexus SAM takes into consideration the value of net indirect taxes, which were estimated for the National Accounts, in order subsequently to calculate the recurrent fiscal deficit of the government. 
from official national accounts data. Second, these total values are disaggregated across commodities using expenditure shares from the IOT/SUT. In some cases, countries report the composition of GFCF on an annual basis, in which case this information is used in place of the IOT/SUT shares. The same is true for stock changes, although most countries only report detailed stock changes when a new IOT/SUT is produced during the rebasing of national accounts.

Although commodity level stock changes in Nexus SAMs typically deviate from national accounts, this is not overly concerning since they are usually an exogenous decision variable in economywide models.

\section{Inventory or stock change adjustment}

(Savings | Investment)

Definition: The accumulation of stocks for sale in subsequent years are added to the amount of savings available in the country (and a depletion of stocks reduces savings). For example, if an activity produces a machine this year for sale next year then they are effectively saving the value of the machine (or investing in future sales). This transfer of total stock changes to the savings account was not shown in Table 1, because it nets to zero in SAMs that aggregate gross fixed capital formation (GFCF) and changes in stocks.

Estimation: This is a residual balancing item for the change in stocks account (see Entry 29). The total value of stock changes is paid to the savings account. A positive value means a net accumulation of stocks and a negative value means a net depletion.

\section{Exports}

(Commodities | Rest of World)

Definition: Value of goods and services exported abroad.

Estimation: The total value of exports is taken from national accounts, and this is then disaggregated into total goods and total services using current account data from the IMF's BOPS (i.e., BPM6 codes BXG for "goods credit" and BXS for "services credit"). BOPS provides detailed information on services exports by commodity and this is used to assign exports to service commodities in the SAM (see Table A5 in the appendix). Goods exports are disaggregated across commodities using 6-digit HS gross export flows from the United Nations Commodity Trade Statistics (COMTRADE) database (UNSD 2015).

\section{Foreign transfers to factors}

\section{(Factors | Rest of World)}

Definition: Labor, land and capital incomes received from the rest of the world. For example, workers belonging to domestic households may earn some or all of their labor incomes working in a foreign country and this income may be repatriated. Similarly, domestically-owned companies may repatriate profits earned abroad.

Estimation: Factor transfers from the rest of the world are from the IMF's BOPS. Labor receipts are "compensation of employees, credit" (BPM6 code BXIPCE). Capital receipts are "investment income, credit" (BPM6 BXIPI), which includes, amongst others, income on foreign equity and investment funds.

\section{Foreign transfers to enterprises}

\section{(Enterprises| Rest of World)}

Definition: Secondary income transfers from the rest of the world to domestic financial and nonfinancial enterprises.

Estimation: The value of enterprise foreign receipts comes from the IMF's BOPS. This includes "other transfers, credit" (BPM6 code BXISOOT). 


\section{Foreign transfers to households}

\section{(Households| Rest of World)}

Definition: Secondary income transfers from households to the rest of the world. For example, households may receive remittance incomes from family members working abroad.

Estimation: The value of household foreign incomes comes from the IMF's BOPS. This includes "personal transfers, credit" (BPM6 code BXISOPT). Transfers are disaggregated across household groups in the SAM using information from national household surveys that capture the amount of remittances households received from abroad.

\section{Foreign transfers to government (Government | Rest of World)}

Definition: Transfers from the rest of the world to the government. For example, government may receive foreign aid from other countries.

Estimation: The value of government foreign receipts comes from the IMF's BOPS, and this is cross-checked against the IMF's GFS. BOPS-based receipts include "general government transfers, credit" under secondary income (BPM6 code BXISG). GFS-based payments include grants received from foreign governments and international organizations (GFSM code 131 and 132).

\section{Foreign savings}

(Savings | Rest of World)

Definition: Current account balance equal to total foreign capital or savings inflows.

Estimation: This is the residual balancing item for the rest of world account, although it crosschecked against the current account balance reported in the IMF's BOPS (BPM6 code 1). Any deviation from BOPS data - and this is usually small - is due to the Nexus SAM giving preference to total the value of imports and exports reported in national accounts (see Entries 7 and 31).

\section{BALANCING NEXUS SOCIAL ACCOUNTING MATRICES}

Nexus social accounting matrices are constructed in three stages using the IFPRI SAM Building Toolkit. The toolkit uses a standardized template in Microsoft-Exce ${ }^{\circledR}$ to construct and export an unbalanced SAM to a compilation and balancing program that is executed in the General Algebraic Modeling System (GAMS).

During the first stage of the SAM Toolkit, a Macro SAM is constructed using the data described in previous sections. The three main data sources for the Macro SAM are national accounts, the IMF's Government Finance Statistics (GFS) database, and the IMF Balance of Payments Statistics (BOPS) database. Unfortunately, in many developing countries, these three data sources are not fully reconciled. For example, the total value of exports and imports in national accounts may not exactly match the values appearing in BOPS. Preference is given to certain data sources. For instance, Nexus SAMs always use national accounts data instead of trade data from BOPS or government consumption spending estimates from GFS. Similarly, preference is given BOPS over GFS when estimating transfers between the government and the rest of the world. Row and column totals in the Macro SAM are reconciled manually through various residual balancing items:

- Marketed supply balances the activity accounts (see Entry 4)

- Transfers to households or enterprises balances the factor accounts (see Entry 8 and 9)

- Transfers to households balances the enterprise account (see Entry 12)

- Household and government savings balance the household and government accounts (see Entries 21 and 26)

- Foreign savings balances the rest of world account (see Entry 36). 
During the second stage, income and expenditure shares derived from surveys and other sources are used to disaggregate the Macro SAM entries across detailed activities, commodities, factors and households. Sectoral and product data is used to disaggregate production and trade, and survey data is used to disaggregate factor and household incomes and consumer demand. There are always imbalances between the level of supply and demand for commodities and between household incomes and expenditures. These imbalances are manually checked for misclassification issues and logical errors in data collection and reporting. However, imbalances invariably remain, and so Nexus SAMs use cross-entropy estimation techniques to reconcile row and column totals at the detailed commodity and household level. For more information on cross-entropy-based reconciliation of SAM accounts, see Robinson et al. (2001).

Finally, in the third stage, Standard Nexus SAM entries are further disaggregated to include sex-disaggregated and regional information. As above, separating activities, factors, and households always introduces new imbalances. These are reconciled using a second round of cross-entropy estimation techniques.

\section{EGYPT SOCIAL ACCOUNTING MATRIX AND DATA SOURCES}

The 2015 Egypt SAM follows the Standard Nexus structure, as described in Section 2. Table 9 lists the data sources used to construct the SAM. All major data sources are consistent with those used for Standard Nexus SAMs, as described in Section 3.

Table 9. Summary of Data Sources for the Egypt Social Accounting Matrix

\begin{tabular}{|c|c|c|c|}
\hline Data needs & Data year & Country data sources & Reference \\
\hline \multicolumn{4}{|l|}{ Macroeconomic structure } \\
\hline National accounts & 2015 & $\begin{array}{l}\text { National accounts, 2007/08 rebased } \\
\text { series }\end{array}$ & MoP (2017) \\
\hline Government finance & 2015 & GFS2014 online database & IMF (2016a) \\
\hline Balance of payments & 2015 & BPM6 online database & IMF (2016b) \\
\hline \multicolumn{4}{|l|}{ Input-output table (IOT) } \\
\hline Aggregate structure & 2013 & Supply-use table & CAPMAS (2016b) \\
\hline Agriculture subsectors & 2010/11 & $\begin{array}{l}\text { 2010/2011 Social Accounting Matrix } \\
\text { for Egypt }\end{array}$ & CAPMAS (2016a) \\
\hline Industrial subsectors & 2013 & Economic Census & CAPMAS (2017a) \\
\hline \multicolumn{4}{|l|}{ Disaggregating activities } \\
\hline Aggregate sectors & 2015 & $\begin{array}{l}\text { National accounts, 2007/08 rebased } \\
\text { series }\end{array}$ & MoP (2016) \\
\hline Crops and livestock subsectors & 2014 & FAOSTAT online database & FAO (2016) \\
\hline $\begin{array}{l}\text { Regional disaggregation of crop } \\
\text { production }\end{array}$ & 2014 & crops_reshaped Stata dataset & CAPMAS \\
\hline $\begin{array}{l}\text { Regional disaggregation of livestock } \\
\text { production }\end{array}$ & 2014 & $\begin{array}{l}\text { Excel files from Economic Affairs } \\
\text { Sector }\end{array}$ & MALR (2015a) \\
\hline $\begin{array}{l}\text { Regional disaggregation of fish } \\
\text { production }\end{array}$ & 2014 & $\begin{array}{l}\text { Excel files from Economic Affairs } \\
\text { Sector }\end{array}$ & MALR (2015b) \\
\hline Industrial subsectors & 2013 & Economic Census & CAPMAS (2017a) \\
\hline $\begin{array}{l}\text { Regional disaggregation of industrial } \\
\text { production }\end{array}$ & 2013 & Economic Census & CAPMAS (2017a) \\
\hline \multicolumn{4}{|l|}{ Disaggregating commodities } \\
\hline Private consumption & 2015 & $\begin{array}{l}\text { Household Income, Expenditure, } \\
\text { and Consumption Survey }\end{array}$ & CAPMAS (2017b) \\
\hline Public consumption & 2013 & Use table & CAPMAS (2016b) \\
\hline Gross fixed capital formation & 2013 & Use table & CAPMAS (2016b) \\
\hline
\end{tabular}




\begin{tabular}{lcll}
\hline \multicolumn{1}{c}{ Data needs } & Data year & Country data sources & \multicolumn{1}{c}{ Reference } \\
\hline Goods trade & 2015 & COMTRADE online database & UNCTAD (2016) \\
Services trade & 2015 & BPM6 online database & IMF (2016b) \\
Indirect tax rates & 2013 & Supply-use table & CAPMAS (2016b) \\
& 2014 & TRAINS Most Favored Nation rates & UNCTAD (2015) \\
Subsidy rates & 2013 & Supply-use table & CAPMAS (2016b) \\
& $2012 / 2013-$ & Ministry of Finance Fiscal & Ministry of \\
& $2014 / 2015$ & Statements & Finance \\
Transaction cost margins & 2013 & Supply-use table & CAPMAS (2016b) \\
Disaggregating labor & 2015 & Household Income, Expenditure, & CAPMAS (2017b) \\
& \multicolumn{3}{c}{ and Consumption Survey } \\
Disaggregating households & 2015 & Household Income, Expenditure, & CAPMAS (2017b) \\
& \multicolumn{3}{c}{ and Consumption Survey } \\
\hline
\end{tabular}

Activities: Egypt's national accounts were rebased using a 2007/08 base year and provided GDP estimates for 23 sectors, which were disaggregated to the Nexus 86 activities using (i) crop production and price data from FAOSTAT (see Section 3); and (ii) industrial data from the 2013 Economic Census. An updated IOT was estimated using (i) the technical coefficients derived from the 2013 SUT containing 97 activities and 79 commodities, which were aggregated to the Nexus 86 activities using the ISIC Revision 4 concordance (see Table A1 in the appendix); (ii) technical coefficients for agriculture subsectors from the 2010/2011 Social Accounting Matrix for Egypt; and (iii) intermediate consumption from the 2013 Economic Census 2013.

Commodities: National accounts report GDP by expenditure group, i.e., private and public consumption, investment demand, and exports and imports. These groups were disaggregated across the Nexus commodities using the following data:

- Six-digit COMTRADE and itemized IMF BOPS data were used to disaggregate international goods and services trade, respectively.

- The 2015 Household Income, Expenditure, and Consumption Survey (HIEC), which is a nationally-representative household survey, was used to disaggregate total private consumption spending across activities and commodities.

- Public consumption spending was disaggregated across public administration, health, and education using GDP information from national accounts, after subtracting other sources of consumption and intermediate demand.

- Initial indirect tax rates were estimated using sales tax collection rates calculated from the 2013 SUT. Import tariffs were extracted from UNCTAD's Trade Analysis Information System (TRAINS) and scaled to match data on total import duties collected from the IMF's GFS database. Subsidy rates were estimated based on subsidy information from the 2013 SUT.

Labor: The updated IOT separates sectoral GDP into compensation of employees and gross operating surplus. Labor value-added was disaggregated using sector-level income shares of household members derived from the 2015 HIEC. This survey provides information on wage earnings, as well as farm and non-farm enterprise revenues.

Households: Household incomes and expenditures were disaggregated across representative household groups using information from the 2015 HIEC. Households receive factor incomes based on reported earnings of individual household members. The value-added generated by cropland and livestock capital were paid to household groups based on their reported farm enterprise revenues. Direct tax payments were assumed to be proportional to secondary and tertiary-educated workers' wage and non-farm enterprise earnings. Finally, transfers received from the government and the rest of the world were assigned to households using information from the survey. More specifically, 
the ratio of transfer earnings to total household consumption was used to estimate initial transfer incomes. These were then scaled uniformly across all households in order to match the total value of transfers appearing in government and balance of payments statistics.

Data file: The Microsoft Excel ${ }^{\circledR}$ file containing the 2015 regionalized SAM for Egypt ("Egypt Regional SAM_2015.xIsx") includes two worksheets:

- Notes: Description of the Egypt Nexus SAM accounts.

- Egypt-SAM: The 2015 regional SAM with the standard 70-sector Nexus structure.

The number of activities/commodities used in the SAM description is based on the number of Standard Nexus accounts considered when constructing the SAM (see Table 2).

The 2015 regionalized SAM presents the latest consistent economy-wide dataset for Egypt. This paper provides a detailed description of the underlying data used to construct the SAM. For anyone who is interested in more structural details or would like to use the SAM for economic analysis, the data file can be downloaded from the dataset webpage on IFPRI's website:

http://www.ifpri.org/Publication \& Tools: Dataset. 


\section{REFERENCES}

\section{General References}

EC, IMF, OECD, UN and World Bank (European Commission, International Monetary Fund, Organization for Economic Cooperation and Development, United Nations, and World Bank). 2009. System of National Accounts 2008. New York NY, USA: EC, IMF, OECD, UN and World Bank.

FAO (Food and Agriculture Organization of the United Nations). 2015. FAO Statistical Databases (FAOSTAT). Rome, Italy: FAO.

IMF (International Monetary Fund). 2014a. BPM6 Compilation Guide: Companion Document to the Sixth Edition of the Balance of Payments and International Investment Position Manual. Washington DC, USA: IMF.

IMF (International Monetary Fund). 2014b. Government Finance Statistics Manual 2014. Washington DC, USA: IMF.

Pyatt, G. and J. Round. 1985. Social Accounting Matrices: A Basis for Planning. Washington DC, USA: World Bank.

Reinert, K.A., and D.W. Roland-Holst. 1997. "Social Accounting Matrices." In Francois, J.F., and K.A. Reinert (eds.) Applied Methods for Trade Policy Analysis: A Handbook. New York NY, USA: Cambridge University Press.

Robinson, S., A. Cattaneo and M. El-Said. 2001. "Updating and Estimating a Social Accounting Matrix Using Cross Entropy Methods." Economic Systems Research 13 (1): 47-64.

UNCTAD (United Nations Conference on Trade and Development). 2015. Trade Analysis Information System (TRAINS). Geneva, Switzerland: UNCTAD.

UNDESA (United Nations Department for Economic and Social Affairs). 2002. International Standard Industrial Classification of All Economic Activities (ISIC): Revision 3.1. Statistical Papers, Series M No. 4 Rev. 3.1. New York NY, USA: Statistics Division, UNDESA.

UNDESA (United Nations Department for Economic and Social Affairs). 2008. International Standard Industrial Classification of All Economic Activities (ISIC): Revision 4. Statistical Papers, Series M No. 4 Rev. 4. New York NY, USA: Statistics Division, UNDESA.

UNSD (United Nations Statistics Division). 2015. Commodity Trade Statistics Database. New York NY, USA: UNSD.

World Bank. 2015. World Development Indicators. Washington DC, USA: World Bank.

\section{Country-Specific References}

Abdel Meguid, M. 2017. "Key Features of the Egypt's Water and Agricultural Resources." In: The Handbook of Environmental Chemistry. pp. 1-61. Berlin \& Heidelberg: Springer.

Abou-Ali, H., and H. Kheir-El-Din. 2010. Economic efficiency of crop production in Egypt. Egyptian Center for Economic Studies (ECES). Working paper series 155. Cairo: ECES.

CAPMAS (Central Agency for Public Mobilization and Statistics). 2016a. A Disaggregated Social Accounting Matrix 2010/2011 for Policy Analysis in Egypt. Cairo: CAPMAS.

CAPMAS (Central Agency for Public Mobilization and Statistics). 2016b. Supply Use Table 2013. Cairo: CAPMAS.

CAPMAS (Central Agency for Public Mobilization and Statistics). 2017a. Economic Census, 2013. Cairo: CAPMAS.

CAPMAS (Central Agency for Public Mobilization and Statistics). 2017b. Household Income, Expenditure, and Consumption Survey, 2015. Cairo: CAPMAS.

MALR (Ministry of Agriculture and Land Reclamation). 2015a. Statistics of Livestock 2014. Economic Affairs Sector. Cairo: MALR.

MALR (Ministry of Agriculture and Land Reclamation). 2015b. Statistics of Fish, Insect Production and FoodManufacturing 2014. Economic Affairs Sector. Cairo: MALR.

MoP (Ministry of Planning Monitoring and Administrative Reform). 2017. Revised National Accounts Estimates for Egypt: Base Year 2007/08. Cairo: MoP. 


\section{APPENDICES}

Table A1. Detailed Classification of Nexus 86 Activity Accounts

\begin{tabular}{|c|c|c|}
\hline \multicolumn{2}{|r|}{ Nexus Activity } & International Standard Industrial Classification (ISIC) Revision 4 \\
\hline Code & Description & Code $\quad$ Description \\
\hline maiz & Maize & 0111 Growing of cereals (except rice), leguminous crops and oil seeds \\
\hline sorg & Sorghum and millet & 0111 Growing of cereals (except rice), leguminous crops and oil seeds \\
\hline rice & Rice & 0112 Growing of rice \\
\hline whea & Wheat and barley & 0111 Growing of cereals (except rice), leguminous crops and oil seeds \\
\hline ocer & Other cereals & 0111 Growing of cereals (except rice), leguminous crops and oil seeds \\
\hline puls & Pulses & 0111 Growing of cereals (except rice), leguminous crops and oil seeds \\
\hline gnut & Groundnuts & 0111 Growing of cereals (except rice), leguminous crops and oil seeds \\
\hline oils & Other oilseeds & 0111 Growing of cereals (except rice), leguminous crops and oil seeds \\
\hline cass & Cassava & 0113 Growing of vegetables and melons, roots and tubers \\
\hline ipot & Irish potatoes & 0113 Growing of vegetables and melons, roots and tubers \\
\hline spot & Sweet potatoes & 0113 Growing of vegetables and melons, roots and tubers \\
\hline root & Other roots & 0113 Growing of vegetables and melons, roots and tubers \\
\hline leaf & Leafy vegetables & 0113 Growing of vegetables and melons, roots and tubers \\
\hline vege & Vegetables & 0113 Growing of vegetables and melons, roots and tubers \\
\hline sugr & Sugar cane & 0114 Growing of sugar cane \\
\hline toba & Tobacco & 0115 Growing of tobacco \\
\hline cott & Cotton and fibers & 0116 Growing of fiber crops \\
\hline nuts & Nuts & 0125 Growing of other tree and bush fruits and nuts \\
\hline bana & Banana and plantains & 0125 Growing of other tree and bush fruits and nuts \\
\hline frui & Fruits & 0121 Growing of grapes \\
\hline & & 0122 Growing of tropical and subtropical fruits \\
\hline & & 0123 Growing of citrus fruits \\
\hline & & 0124 Growing of pome fruits and stone fruits \\
\hline & & 0125 Growing of other tree and bush fruits and nuts \\
\hline & & 0126 Growing of oleaginous fruits \\
\hline coco & Cocoa & 0127 Growing of beverage crops \\
\hline coff & Coffee & 0127 Growing of beverage crops \\
\hline teal & Tea & 0127 Growing of beverage crops \\
\hline flwr & Cut flowers & 0130 Plant propagation \\
\hline rubb & Rubber & 0119 Growing of other non-perennial crops \\
\hline ocrp & Other crops & 0119 Growing of other non-perennial crops \\
\hline & & 0128 Growing of spices, aromatic, drug and pharmaceutical crops \\
\hline & & 0129 Growing of spices, aromatic, drug and pharmaceutical crops \\
\hline & & 0161 Support activities for crop production \\
\hline & & 0163 Post-harvest crop activities \\
\hline & & 0164 Seed processing for propagation \\
\hline catt & Cattle & 0141 Raising of cattle and buffaloes \\
\hline milk & Raw milk & 0141 Raising of cattle and buffaloes \\
\hline poul & Poultry & 0146 Raising of poultry \\
\hline eggs & Eggs & 0146 Raising of poultry \\
\hline smlr & Small ruminants & 0144 Raising of sheep and goats \\
\hline oliv & Other livestock & 0142 Raising of horses and other equines \\
\hline & & 0143 Raising of camels and camelids \\
\hline & & 0145 Raising of swine/pigs \\
\hline & & 0149 Raising of other animals \\
\hline & & 0162 Support activities for animal production \\
\hline
\end{tabular}




\begin{tabular}{|c|c|c|}
\hline \multicolumn{2}{|r|}{ Nexus Activity } & International Standard Industrial Classification (ISIC) Revision 4 \\
\hline Code & Description & Code $\quad$ Description \\
\hline & & 0170 Hunting, trapping and related service activities \\
\hline fore & Forestry & 02xx Forestry and logging \\
\hline aqua & Aquaculture & 032x Aquaculture \\
\hline fish & Fishing & 031x Fishing \\
\hline coal & Coal and lignite & 05xx Mining of coal and lignite \\
\hline coil & Crude oil & 061x Extraction of crude petroleum \\
\hline ngas & Natural gas & 062x Extraction of natural gas \\
\hline \multirow[t]{3}{*}{ omin } & Other mining & $07 x x$ Mining of metal ores \\
\hline & & $08 x x$ Other mining and quarrying \\
\hline & & 09xx Mining support service activities \\
\hline meat & Meat processing & 101x Processing and preserving of meat \\
\hline fsea & Fish and seafood processing & 102x Processing and preserving of fish, crustaceans and mollusks \\
\hline fveg & Fruit \& vegetable processing & $103 x$ Processing and preserving of fruit and vegetables \\
\hline foil & Fats and oils & 104x Manufacture of vegetable and animal oils and fats \\
\hline dair & Dairy & 105x Manufacture of dairy products \\
\hline $\mathrm{mmll}$ & Maize milling & 1061 Manufacture of grain mill products \\
\hline smll & Sorghum and millet milling & 1061 Manufacture of grain mill products \\
\hline rmll & Rice milling & 1061 Manufacture of grain mill products \\
\hline wmll & Wheat and barley milling & 1061 Manufacture of grain mill products \\
\hline gmll & Other grain milling & 106x Manufacture of grain mill products, starches and starch products \\
\hline sref & Sugar refining & 1072 Manufacture of sugar \\
\hline pcof & Coffee processing & 1079 Manufacture of coffee products \\
\hline ptea & Tea processing & 1079 Manufacture of tea products \\
\hline food & Other foods & $\begin{array}{l}\text { 107x Manufacture of other food products (excl. sugar: } 1072 \text { above, } \\
\text { coffee and tea products) }\end{array}$ \\
\hline feed & Animal feed & 108x Manufacture of prepared animal feeds \\
\hline beve & Beverages & $11 x x$ Manufacture of beverages \\
\hline ptob & Tobacco processing & 12xx Manufacture of tobacco products \\
\hline yarn & Yarn & 1311 Preparation and spinning of textile fibers \\
\hline text & Textiles & 13xx Manufacture of textiles \\
\hline clth & Clothing & 14xx Manufacture of wearing apparel \\
\hline leat & Leather and footwear & 15xx Manufacture of leather and related products \\
\hline wood & Wood products & $\begin{array}{l}\text { 16xx Manufacture of wood and of products of wood and cork, except } \\
\text { furniture }\end{array}$ \\
\hline \multirow[t]{2}{*}{ papr } & Paper and publishing & 17xx Manufacture of paper and paper products \\
\hline & & 18xx Printing and reproduction of recorded media \\
\hline petr & Petroleum & 19xx Manufacture of coke and refined petroleum products \\
\hline \multirow[t]{2}{*}{ fert } & Fertilizer and pesticides & 2012 Manufacture of fertilizers and nitrogen compounds \\
\hline & & 2021 Manufacture of pesticides and other agrochemical products \\
\hline \multirow[t]{3}{*}{ chem } & Other chemicals & $\begin{array}{l}\text { 20xx Manufacture of chemicals and chemical products (excl. } 2012 \text { and } \\
2021 \text { above) }\end{array}$ \\
\hline & & $\begin{array}{l}21 \times x \text { Manufacture of basic pharmaceutical products and pharmaceutical } \\
\text { preparations }\end{array}$ \\
\hline & & 22xx Manufacture of rubber and plastics products \\
\hline nmet & Non-metal minerals & 23xx Manufacture of other non-metallic mineral products \\
\hline \multirow[t]{2}{*}{ metl } & Metals and metal products & 24xx Manufacture of basic metals \\
\hline & & $\begin{array}{l}25 x x \text { Manufacture of fabricated metal products, except machinery and } \\
\text { equipment }\end{array}$ \\
\hline \multirow[t]{2}{*}{ equi } & Electrical equipment & 26xx Manufacture of computer, electronic and optical products \\
\hline & & $27 x x$ Manufacture of electrical equipment \\
\hline
\end{tabular}




\begin{tabular}{|c|c|c|c|}
\hline \multicolumn{2}{|r|}{ Nexus Activity } & \multicolumn{2}{|r|}{ International Standard Industrial Classification (ISIC) Revision 4} \\
\hline Code & Description & Code & Description \\
\hline mach & Machinery \& other equipment & $28 x x$ & Manufacture of machinery and equipment n.e.c. \\
\hline \multirow[t]{2}{*}{ vehi } & Vehicles \& transport equipment & $29 x x$ & Manufacture of motor vehicles, trailers and semi-trailers \\
\hline & & $30 x x$ & Manufacture of other transport equipment \\
\hline \multirow[t]{3}{*}{ oman } & Other manufacturing & $31 x x$ & Manufacture of furniture \\
\hline & & $32 x x$ & Other manufacturing \\
\hline & & $33 x x$ & Repair and installation of machinery and equipment \\
\hline elec & Electricity, gas and steam & $35 x x$ & Electricity, gas, steam and air conditioning supply \\
\hline \multirow[t]{3}{*}{ watr } & Water supply and sewage & $36 x x$ & Water collection, treatment and supply \\
\hline & & $37 x x$ & Sewerage \\
\hline & & $38 x x$ & $\begin{array}{l}\text { Waste collection, treatment and disposal activities; materials } \\
\text { recovery }\end{array}$ \\
\hline \multirow[t]{3}{*}{ cons } & Construction & $41 x x$ & Construction of buildings \\
\hline & & $42 x x$ & Civil engineering \\
\hline & & $43 x x$ & Specialized construction activities \\
\hline \multirow[t]{3}{*}{ trad } & Wholesale and retail trade & $45 x x$ & $\begin{array}{l}\text { Wholesale and retail trade and repair of motor vehicles and } \\
\text { motorcycles }\end{array}$ \\
\hline & & $46 x x$ & Wholesale trade, except of motor vehicles and motorcycles \\
\hline & & $47 x x$ & Retail trade, except of motor vehicles and motorcycles \\
\hline \multirow[t]{5}{*}{$\operatorname{tran}$} & Transportation and storage & $49 x x$ & Land transport and transport via pipelines \\
\hline & & $50 x x$ & Water transport \\
\hline & & $51 x x$ & Air transport \\
\hline & & $52 x x$ & Warehousing and support activities for transportation \\
\hline & & $53 x x$ & Postal and courier activities \\
\hline hotl & Accommodation \& food services & $55 x x$ & Accommodation \\
\hline rest & Restaurants and food services & $56 x x$ & Food and beverage service activities \\
\hline \multirow[t]{6}{*}{ comm } & Information and communication & $58 x x$ & Publishing activities \\
\hline & & $59 x x$ & $\begin{array}{l}\text { Motion picture, video, TV program production, sound and music } \\
\text { publishing }\end{array}$ \\
\hline & & $60 x x$ & Programming and broadcasting activities \\
\hline & & $61 x x$ & Telecommunications \\
\hline & & $62 x x$ & Computer programming, consultancy and related activities \\
\hline & & $63 x x$ & Information service activities \\
\hline \multirow[t]{3}{*}{ fsrv } & Finance \& insurance & $64 x x$ & Financial service activities, except insurance and pension funding \\
\hline & & $65 x x$ & $\begin{array}{l}\text { Insurance, reinsurance and pension funding, except compulsory } \\
\text { social security }\end{array}$ \\
\hline & & $66 x x$ & Activities auxiliary to financial service and insurance activities \\
\hline real & Real estate activities & $68 x x$ & Real estate activities \\
\hline \multirow[t]{10}{*}{ bsrv } & Business services & $69 x x$ & Legal and accounting activities \\
\hline & & $70 x x$ & Activities of head offices; management consultancy activities \\
\hline & & $71 x x$ & $\begin{array}{l}\text { Architectural and engineering activities; technical testing and } \\
\text { analysis }\end{array}$ \\
\hline & & $72 x x$ & Scientific research and development \\
\hline & & $73 x x$ & Advertising and market research \\
\hline & & $74 x x$ & Other professional, scientific and technical activities \\
\hline & & $75 x x$ & Veterinary activities \\
\hline & & $77 x x$ & Rental and leasing activities \\
\hline & & $78 x x$ & Employment activities \\
\hline & & $79 x x$ & $\begin{array}{l}\text { Travel agency, tour operator, reservation service and related } \\
\text { activities }\end{array}$ \\
\hline
\end{tabular}




\begin{tabular}{|c|c|c|}
\hline \multirow[b]{2}{*}{ Code } & Nexus Activity & International Standard Industrial Classification (ISIC) Revision 4 \\
\hline & Description & Code Description \\
\hline & & 80xx Security and investigation activities \\
\hline & & 81xx Services to buildings and landscape activities \\
\hline & & $\begin{array}{l}\text { 82xx Office administrative, office support and other business support } \\
\text { activities }\end{array}$ \\
\hline padm & Public administration & 84xx Public administration and defense; compulsory social security \\
\hline educ & Education & 85xx Education \\
\hline \multirow[t]{3}{*}{ heal } & Health and social work & 86xx Human health activities \\
\hline & & 87xx Residential care activities \\
\hline & & 88xx Social work activities without accommodation \\
\hline \multirow[t]{10}{*}{ osrv } & Other services & 90xx Creative, arts and entertainment activities \\
\hline & & 91xx Libraries, archives, museums and other cultural activities \\
\hline & & 92xx Gambling and betting activities \\
\hline & & 93xx Sports activities and amusement and recreation activities \\
\hline & & 94xx Activities of membership organizations \\
\hline & & 95xx Repair of computers and personal and household goods \\
\hline & & 96xx Other personal service activities \\
\hline & & 97xx Activities of households as employers of domestic personnel \\
\hline & & $\begin{array}{l}\text { 98xx Undifferentiated goods/service activities of private households for } \\
\text { own use }\end{array}$ \\
\hline & & 99xx Activities of extraterritorial organizations and bodies \\
\hline
\end{tabular}

Note: n.e.c. = "not elsewhere considered".

Table A2. Detailed Classification of Nexus 86 Agricultural Activity Accounts

\begin{tabular}{|c|c|}
\hline Code & Description (FAOSTAT crop and livestock product codes in parentheses) \\
\hline maiz & Maize (56) \\
\hline sorg & Millet (79); Sorghum (83) \\
\hline rice & Paddy rice $(27)$ \\
\hline whea & Wheat (15); Barley (44) \\
\hline ocer & $\begin{array}{l}\text { Rye (71); Oats (75); Buckwheat (89); Quinoa (92); Fonio (94); Triticale (97); Canary seed (101); Mixed } \\
\text { grain (103); Cereals not elsewhere specified (108) }\end{array}$ \\
\hline puls & $\begin{array}{l}\text { Dry beans (176); Dry broad beans and horse beans (181); Dry peas (187); Chick peas (191); Dry cow } \\
\text { peas (195); Pigeon peas (197); Lentils (201); Bambara beans (203); Vetches (205); Lupins (210); Pulses } \\
\text { not elsewhere specified (211) }\end{array}$ \\
\hline gnut & Groundnuts with shell (242) \\
\hline oils & $\begin{array}{l}\text { Soybeans (236); Coconuts (249); Palm oil fruit (254); Palm kernels (256); Palm oil (257); Olives (260); } \\
\text { Karite nuts (sheanuts) (263); Castor oil seed (265); Sunflower seed (267); Rapeseed (270); Tung } \\
\text { nuts (275); Jojoba seed (277); Safflower seed (280); Sesame seed (289); Mustard seed (292); Poppy } \\
\text { seed (296); Melonseed (299); Tallowtree seed (305); Vegetable tallow (306); Stillingia oil (307); } \\
\text { Cottonseed (329); Linseed (333); Hempseed (336); Oilseeds not elsewhere specified (339) }\end{array}$ \\
\hline cass & Cassava (125) \\
\hline ipot & Potatoes (116) \\
\hline spot & Sweet potatoes (122) \\
\hline root & $\begin{array}{l}\text { Yautia (cocoyam) (135); Taro (cocoyam) (136); Yams (137); Roots and tubers not elsewhere } \\
\text { specified (149) }\end{array}$ \\
\hline leaf & $\begin{array}{l}\text { Cabbages and other brassicas (358); Artichokes (366); Asparagus (367); Lettuce and chicory (372); } \\
\text { Tomatoes (388); Cauliflowers and broccoli (393); Pumpkins, squash and gourds (394); Cucumbers and } \\
\text { gherkins (397); Eggplants (aubergines) (399) }\end{array}$ \\
\hline vege & $\begin{array}{l}\text { Chilies and peppers, green (401); Green onions and shallots (402); Dry onions (403); Garlic (406); Leeks } \\
\text { and other alliaceous vegetables (407); Green beans (414); Green peas (417); Leguminous vegetables not } \\
\text { elsewhere specified (420); String beans (423); Carrots and turnips (426); Okra (430); Green maize (446); }\end{array}$ \\
\hline
\end{tabular}




\begin{tabular}{|c|c|}
\hline Code & Description (FAOSTAT crop and livestock product codes in parentheses) \\
\hline & $\begin{array}{l}\text { Mushrooms and truffles (449); Chicory roots (459); Carobs (461); Fresh vegetables not elsewhere } \\
\text { specified (463) }\end{array}$ \\
\hline sugr & Sugar cane (156); Sugar beet (157); Sugar crops not elsewhere specified (161) \\
\hline toba & Unmanufactured tobacco (826) \\
\hline cott & $\begin{array}{l}\text { Kapok fruit (310); Seed cotton (328); Flax fiber and tow (773); Hemp tow waste (777); Jute (780); } \\
\text { Bastfibers, other (782); Ramie (788); Sisal (789); Agave fibers not elsewhere specified (800); Manila fiber } \\
\text { (abaca) (809); Fiber crops not elsewhere specified (821) }\end{array}$ \\
\hline nuts & $\begin{array}{l}\text { Brazil nuts with shell (216); Cashew nuts with shell (217); Chestnut (220); Almonds with shell (221); } \\
\text { Walnuts with shell (222); Pistachios (223); Kola nuts (224); Hazelnuts with shell (225); Areca nuts (226); } \\
\text { Nuts not elsewhere specified (234) }\end{array}$ \\
\hline bana & Bananas (486); Plantains (489) \\
\hline frui & $\begin{array}{l}\text { Oranges (490); Tangerines, mandarins, clementines and satsumas (495); Lemons and limes (497); } \\
\text { Grapefruit (including pomelos) (507); Citrus fruit not elsewhere specified (512); Apples (515); Pears (521); } \\
\text { Quinces (523); Apricots (526); Sour cherries (530); Cherries (531); Peaches and nectarines (534); Plums } \\
\text { and sloes (536); Stone fruit not elsewhere specified (541); Pome fruit not elsewhere specified (542); } \\
\text { Strawberries (544); Raspberries (547); Gooseberries (549); Currants (550); Blueberries (552); } \\
\text { Cranberries (554); Berries not elsewhere specified (558); Grapes (560); Watermelons (567); Other } \\
\text { melons (including cantaloupes) (568); Figs (569); Mangoes, mangosteens, and guavas (571); } \\
\text { Avocados (572); Pineapples (574); Dates (577); Persimmons (587); Cashew apple (591); Kiwi fruit (592); } \\
\text { Papayas (600); Fresh tropical fruit not elsewhere specified (603); Fresh fruit not elsewhere specified (619) }\end{array}$ \\
\hline coco & Cocoa beans (661) \\
\hline coff & Green coffee (656) \\
\hline teal & Tea (667); Mata (671); Tea not elsewhere specified (674) \\
\hline flwr & Not reported in FAOSTAT \\
\hline rubb & Natural rubber (836); Natural gums (839) \\
\hline ocrp & $\begin{array}{l}\text { Hops (677); Pepper (piper spp.) (687); Dry chilies and peppers (689); Vanilla (692); Cinnamon } \\
\text { (canella) (693); Cloves (698); Nutmeg, mace and cardamoms (702); Anise, badian, fennel and } \\
\text { coriander (711); Ginger (720); Spices not elsewhere specified (723); Peppermint (748); Dried } \\
\text { pyrethrum (754) }\end{array}$ \\
\hline catt & Cattle meat (867); Indigenous cattle meat (944); Live weight cattle meat (945) \\
\hline milk & $\begin{array}{l}\text { Whole fresh cow milk (882); Whole fresh buffalo milk (951); Whole fresh sheep milk (982); Whole fresh } \\
\text { goat milk (1020); Whole fresh camel milk (1130) }\end{array}$ \\
\hline poul & $\begin{array}{l}\text { Chicken meat (1058); Duck meat (1069); Indigenous duck meat (1070); Live weight duck meat (1071); } \\
\text { Goose and guinea fowl meat (1073); Indigenous goose meat (1077); Live weight goose meat (1078); } \\
\text { Turkey meat (1080); Indigenous bird meat not elsewhere specified (1084); Other live weight poultry } \\
\text { meat (1085); Indigenous turkey meat (1087); Live weight turkey meat (1088); Bird meat not elsewhere } \\
\text { specified (1089); Indigenous chicken meat (1094); Live weight chicken meat (1095) }\end{array}$ \\
\hline eggs & Hen eggs in shell (1062); Other bird eggs in shell (1091) \\
\hline smlr & $\begin{array}{l}\text { Sheep meat (977); Greasy wool (987); Indigenous sheep meat (1012); Live weight sheep meat (1013); } \\
\text { Goat meat (1017); Indigenous goat meat (1032); Live weight goat meat (1033) }\end{array}$ \\
\hline oliv & $\begin{array}{l}\text { Buffalo meat (947); Indigenous buffalo meat (972); Live weight buffalo meat (973); Pig meat (1035); } \\
\text { Indigenous pig meat (1055); Live weight pig meat (1056); Horse meat (1097); Ass meat (1108); Mule } \\
\text { meat (1111); Indigenous horse meat (1120); Live weight horse meat (1121); Indigenous ass meat (1122); } \\
\text { Live weight ass meat (1123); Indigenous mule meat (1124); Live weight mule meat (1125); Camel } \\
\text { meat (1127); Indigenous camel meat (1137); Live weight camel meat (1138); Rabbit meat (1141); } \\
\text { Indigenous rabbit meat (1144); Live weight rabbit meat (1145); Other rodent meat (1151); Indigenous } \\
\text { rodent meat (1154); Live weight rodent meat (1155); Other camelid meat (1158); Indigenous other } \\
\text { camelid meat (1111); Live weight other camelids meat (1162); Game meat (1163); Meat not elsewhere } \\
\text { specified (1166); Snails (1176); Natural honey (1182); Beeswax (1183); Silk-worm cocoons (1185) }\end{array}$ \\
\hline
\end{tabular}


Table A3. Concordance between Nexus 70 and Nexus 86 Activity Accounts

\begin{tabular}{|c|c|c|c|c|c|}
\hline Nexus description & N70 & N86 & Nexus description & N70 & N86 \\
\hline Maize & maiz & maiz & Fats and oils & foil & foil \\
\hline Sorghum and millet & sorg & sorg & Grain milling & gmll & $\mathrm{mmll}$ \\
\hline Rice & rice & rice & Grain milling & gmll & smll \\
\hline Other cereals & whea & whea & Grain milling & gmll & rmll \\
\hline Other cereals & ocer & ocer & Grain milling & gmll & wmll \\
\hline Pulses & puls & puls & Grain milling & gmll & gmll \\
\hline Groundnuts & gnut & gnut & Sugar refining & sref & sref \\
\hline Other oilseeds & oils & oils & Other foods and feed & food & pcof \\
\hline Cassava & cass & cass & Other foods and feed & food & ptea \\
\hline Other roots & root & ipot & Other foods and feed & food & food \\
\hline Other roots & root & spot & Other foods and feed & feed & feed \\
\hline Other roots & root & root & Beverages & beve & beve \\
\hline Vegetables & vege & leaf & Tobacco processing & ptob & ptob \\
\hline Vegetables & vege & vege & Textiles & text & yarn \\
\hline Sugarcane & sugr & sugr & Textiles & text & text \\
\hline Tobacco & toba & toba & Clothing & clth & clth \\
\hline Cotton and fibres & $\operatorname{cott}$ & cott & Leather and footwear & leat & leat \\
\hline Fruits and nuts & frui & nuts & Wood and paper products & wood & wood \\
\hline Fruits and nuts & frui & bana & Wood and paper products & papr & papr \\
\hline Fruits and nuts & frui & frui & Petroleum products & petr & petr \\
\hline Coffee and tea & teal & teal & Other chemicals & fert & fert \\
\hline Coffee and tea & coff & coff & Other chemicals & chem & chem \\
\hline Cocoa & coco & coco & Non-metal minerals & nmet & nmet \\
\hline Other crops & flwr & flwr & Metals and metal products & metl & metl \\
\hline Other crops & ocrp & rubb & Machinery and equipment & mach & mach \\
\hline Other crops & ocrp & ocrp & Machinery and equipment & equi & equi \\
\hline Cattle and milk & catt & catt & Machinery and equipment & vehi & vehi \\
\hline Cattle and milk & milk & milk & Other manufacturing & oman & oman \\
\hline Poultry and eggs & poul & poul & Electricity, gas and steam & elec & elec \\
\hline Poultry and eggs & poul & eggs & Water supply and sewage & watr & watr \\
\hline Other livestock & smlr & smlr & Construction & cons & cons \\
\hline Other livestock & oliv & oliv & Wholesale and retail trade & trad & $\operatorname{trad}$ \\
\hline Forestry & fore & fore & Transportation and storage & $\operatorname{tran}$ & $\operatorname{tran}$ \\
\hline Fisheries & fish & aqua & Accommodation and food services & hotl & hotl \\
\hline Fisheries & fish & fish & Accommodation and food services & hotl & rest \\
\hline Coal and lignite & coal & coal & Information and communication & comm & comm \\
\hline Crude oil & coil & coil & Finance and insurance & fsrv & fsrv \\
\hline Natural gas & ngas & ngas & Real estate activities & real & real \\
\hline Other mining & omin & omin & Business services & bsrv & bsrv \\
\hline Meat, fish and dairy & meat & meat & Public administration & padm & padm \\
\hline Meat, fish and dairy & fsea & fsea & Education & educ & educ \\
\hline Meat, fish and dairy & dair & dair & Health and social work & heal & heal \\
\hline Fruit \& vegetable processing & fveg & fveg & Other services & osrv & osrv \\
\hline
\end{tabular}


Table A4. Detailed Classification of the Government Account

\begin{tabular}{|c|c|c|c|}
\hline \multicolumn{2}{|c|}{ Government Financial Statistics Manual (IMF GFSM 2014) } & \multicolumn{2}{|c|}{$\begin{array}{l}\text { Nexus SAM } \\
\text { Entries* }\end{array}$} \\
\hline Code & Description & Row & Column \\
\hline 1 & Revenue & & \\
\hline 11 & Taxes & & \\
\hline 111 & Taxes on income, profits, and capital gains & & \\
\hline 1111 & Payable by individuals & dtax & hhd-__ \\
\hline 1112 & Payable by corporations and other enterprises & dtax & ent \\
\hline 1113 & Other taxes on income, profits, and capital gains & dtax & ent \\
\hline 112 & Taxes on payroll and workforce & ftax & flab- \\
\hline 113 & Taxes on property & $\mathrm{ftax}$ & fcap-_ \\
\hline 114 & Taxes on goods and services & stax & c_ \\
\hline 115 & Taxes on international trade and transactions & & \\
\hline 1151 & Customs and other import duties & $\operatorname{mtax}$ & c_ \\
\hline 1152 & Taxes on exports & etax & $c_{-}$ \\
\hline 1153 & Profits of export or import monopolies & $\operatorname{mtax}$ & $c$ \\
\hline 1154 & Exchange profits & $\operatorname{mtax}$ & c \\
\hline 1155 & Exchange taxes & $\operatorname{mtax}$ & $c_{-}$ \\
\hline 1156 & Other taxes on international trade and transactions & $\operatorname{mtax}$ & $c$ \\
\hline 116 & Other taxes & dtax & ent \\
\hline 12 & Social contributions & & \\
\hline 121 & Social security contributions & & \\
\hline 1211 & Employee contributions & gov & hhd-_ \\
\hline 1212 & Employer contributions & gov & ent \\
\hline 1213 & Self-employed or unemployed contributions & gov & hhd-__ \\
\hline 1214 & Unallocable contributions & gov & hhd-_ \\
\hline 122 & Other social contributions & & \\
\hline 1221 & Employee contributions & gov & hhd-_ \\
\hline 1222 & Employer contributions & gov & ent \\
\hline 1223 & Imputed contributions & gov & hhd-_ \\
\hline 13 & Grants & gov & row \\
\hline 14 & Other revenue & & \\
\hline 141 & Property income & gov & ment \\
\hline 142 & Sales of goods and services & gov & hhd-__ \\
\hline 143 & Fines, penalties, and forfeits & gov & hhd-_ \\
\hline 144 & Transfers not elsewhere classified & gov & hhd- \\
\hline 145 & Premiums, fees, and nonlife insurance claims & gov & ment \\
\hline 2 & Expense & & \\
\hline 21 & Compensation of employees & $c_{-}$ & gov \\
\hline 22 & Use of goods and services & c_ & gov \\
\hline 23 & Consumption of fixed capital & c & gov \\
\hline 24 & Interest & & \\
\hline 241 & To nonresidents & row & gov \\
\hline 242 & To residents other than general government & ent & gov \\
\hline 243 & To other general government units & ent & gov \\
\hline 25 & Subsidies & ent & gov \\
\hline 26 & Grants & row & gov \\
\hline 27 & Social benefits & hhd-__ & gov \\
\hline 28 & Other expense & ent & gov \\
\hline
\end{tabular}

* Table 5 describes the Nexus SAM account codes. 
Table A5. Detailed Classification of the Rest of World Account

\begin{tabular}{|c|c|c|c|}
\hline \multicolumn{2}{|r|}{ Balance of Payments (IMF BOP6) } & \multicolumn{2}{|c|}{ Nexus SAM Entries* } \\
\hline Code & Description & Row & Column \\
\hline $\mathrm{BCA}$ & Current account & & \\
\hline BGS & Goods and services & & \\
\hline BG & Goods & & \\
\hline $\mathrm{BXG}$ & Credit & C_ & row \\
\hline BMG & Debit & row & c \\
\hline BS & Services & & \\
\hline BXS & Credit & c_ & row \\
\hline BXSR & Maintenance and repair services n.i.e. & ctrad & row \\
\hline BXSTR & Transport & ctran & row \\
\hline BXSTV & Travel & chotl & row \\
\hline BXSOCN & Construction services & ccons & row \\
\hline BXSOIN & Insurance and pension services & cfsrv & row \\
\hline BXSOFI & Financial services & cfsrv & row \\
\hline BXSORL & Charges for the use of intellectual property n.i.e. & cbsrv & row \\
\hline BXSOTCM & Telecommunication, computer, and information services & cbsrv & row \\
\hline BXSOOB & Other business services & cbsrv & row \\
\hline BXSOPCR & Personal, cultural, and recreational services & cosrv & row \\
\hline BXSOGGS & Government goods and services n.i.e. & cpadm & row \\
\hline BMS & Debit & row & C \\
\hline BMSR & Maintenance and repair services n.i.e. & row & ctrad \\
\hline BMSTR & Transport & row & ctran \\
\hline BMSTV & Travel & row & chotl \\
\hline BMSOCN & Construction services & row & ccons \\
\hline BMSOIN & Insurance and pension services & row & cfsrv \\
\hline BMSOFI & Financial services & row & cfsrv \\
\hline BMSORL & Charges for the use of intellectual property n.i.e. & row & cbsrv \\
\hline BMSOTCM & Telecommunication, computer, and information services & row & cbsrv \\
\hline BMSOOB & Other business services & row & cbsrv \\
\hline BMSOPCR & Personal, cultural, and recreational services & row & cosrv \\
\hline BMSOGGS & Government goods and services n.i.e. & row & cpadm \\
\hline BIP & Primary income & & \\
\hline BXIP & Credit & & \\
\hline BXIPCE & Compensation of employees & flab-_ & row \\
\hline BXIPI & Investment income & fcap-_ & row \\
\hline BXIPO & Other primary income & fcap-_ & row \\
\hline BMIP & Debit & & \\
\hline BMIPCE & Compensation of employees & row & flab-_ \\
\hline BMIPI & Investment income & row & fcap-_ \\
\hline BMIPO & Other primary income & row & fcap-_ \\
\hline BIS & Secondary income & & \\
\hline BXIS & Credit & & \\
\hline BXISG & General government & gov & row \\
\hline BXISO & Financial and nonfinancial corporations, households, and NPISHs & & \\
\hline BXISOPT & Personal transfers & hhd-_ & row \\
\hline BXISOOT & Other current transfers & ent & row \\
\hline BMIS & Debit & & \\
\hline BMISG & General government & row & gov \\
\hline BMISO & Financial and nonfinancial corporations, households, and NPISHs & & \\
\hline BMISOPT & Personal transfers & row & hhd- \\
\hline BMISOOT & Other current transfers & row & ent \\
\hline
\end{tabular}

* Table 5 describes the Nexus SAM account codes; Table 1 describes the activities and commodities.

Note: n.i.e. = "not included elsewhere"; NPISH = Non-profit institutions serving households 
Josée Randriamamonjy is a Senior Research Analyst in the Development Strategy and Governance Division (DSGD) of the International Food Policy Research Institute (IFPRI), based in Washington, DC. Mariam Raouf is a Research Associate in IFPRI's Egypt Strategy Support Program, based in Cairo. James Thurlow is a Senior Research Fellow in DSGD of IFPRI, based in Washington, DC.

The Middle East and North Africa Regional Program is managed by the Egypt Strategy Support Program (EgSSP) of the International Food Policy Research Institute (IFPRI). The research presented here was conducted as part of the CGIAR Research Program on Policies, Institutions, and Markets (PIM), which is led by IFPRI. This publication has been prepared as an output of EgSSP. It has not been independently peer reviewed. Any opinions expressed here belong to the author(s) and do not necessarily reflect those of IFPRI, PIM, or CGIAR.

Copyright @ 2019, Remains with the author(s). All rights reserved. 